YAHN RAINER GNECCO MARINHO DA COSTA

DELINEAMENTOS SOBRE A RESPONSABILIDADE OBJETIVA DAS PESSOAS JURÍDICAS POR ATOS DE CORRUPÇÃO NO BRASIL

DISSERTAÇÃO DE MESTRADO

Orientador: Prof. Dr. Gustavo Henrique Justino de Oliveira

UNIVERSIDADE DE SÃO PAULO

FACULDADE DE DIREITO 


\author{
UNIVERSIDADE DE SÃO PAULO \\ PROGRAMA DE PÓS-GRADUAÇÃO
}

\author{
FACULDADE DE DIREITO
}

Yahn Rainer Gnecco Marinho da Costa

\title{
DELINEAMENTOS SOBRE A RESPONSABILIDADE OBJETIVA DAS PESSOAS JURÍDICAS POR ATOS DE CORRUPÇÃO NO BRASIL
}

Dissertação submetida ao Programa de PósGraduação Stricto Sensu em Direito da Faculdade de Direito da Universidade de São Paulo, área de concentração Direito do Estado (DES), subárea Direito Administrativo, apresentado à Banca Examinadora como requisito parcial para obtenção do título de Mestre em Direito, sob orientação do Prof. Doutor Gustavo Henrique Justino de Oliveira. 
Autorizo a reprodução e divulgação total ou parcial deste trabalho, por qualquer meio convencional ou eletrônico, para fins de estudo e pesquisa, desde que citada a fonte.

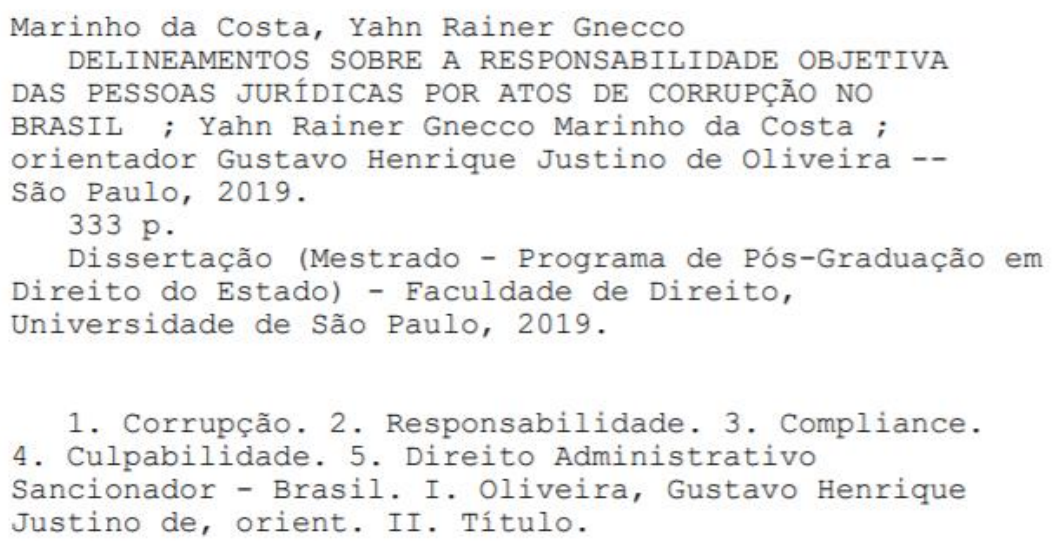


MARINHO DA COSTA, Yahn Rainer Gnecco. Delineamentos sobre a responsabilidade objetiva das pessoas jurídicas por atos de corrupção no Brasil. 2019. 333 p. Dissertação (Mestrado em Direito do Estado) - Faculdade de Direito, Universidade de São Paulo, São Paulo, 2019.

Aprovado em:

\section{Banca Examinadora}

Presidente (Orientador): Professor Dr. Gustavo Henrique Justino de Oliveira Julgamento:

Assinatura:

Prof. Dr.

Instituição:

Julgamento:

Assinatura:

Prof. Dr.

Instituição:

Julgamento:

Assinatura:

Prof. Dr.

Instituição:

Julgamento:

Assinatura: 


\section{AGRADECIMENTOS}

"Tudo o que escrevemos não vale o que deixamos de escrever"

(ANDRADE, Carlos Drummond de. $O$ avesso das coisas:

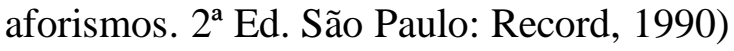

Ora et labora. A máxima monástica beneditina simboliza, muitas vezes, a construção de um trabalho acadêmico permeado por ausências reiteradas, longas horas de estudo, dedicação e restrições à vida do autor, e por sua profissão de fé sobre o valor de tudo o quanto produzido. Enfurnados no labirinto particular de conhecimento que todos acabamos por construir, todavia, mostra-se imprescindível ao longo do ofício o concurso de pessoas e instituições para nos amparar, auxiliar e guiar - tal qual Ariadne com Teseu. Se a presente dissertação possui qualquer mérito é em razão dessas; palavras não bastam para agradecêlas. A culpa do resultado, por óbvio, reside exclusivamente no autor.

Ao Professor Gustavo HenRique Justino DE Oliveira, orientador firme e inspirador, agradeço por ter aberto a este acadêmico desterrado as portas da Universidade de São Paulo, e franqueado absoluta liberdade acadêmica para a construção desta dissertação. Apenas por sua coragem em inovar, ao pioneiramente trazer o estudo da corrupção para a seara do Direito Administrativo, e incentivar uma visão aprofundada e holística do fenômeno corruptivo, é que esta dissertação pôde ser desenvolvida. Agradeço por ter acreditado no potencial do autor.

À Faculdade de Direito do Largo de São Francisco, velha e sempre nova Academia, sinônimo de universidade em todos os seus sentidos, que me proporcionou tanto, em tão pouco tempo, e descerrou a oportunidade para um infindável mundo novo de conhecimento e amadurecimento pessoal.

Ao Professor Sergio Ferraz, incentivador primevo desta pesquisa, mestre e exemplo de gentileza pessoal e acadêmica, que a paixão pelo Direito me proporcionou a honraria de conhecer pessoalmente e desfrutar de seus ensinamentos.

À Professora Helena Regina lobo da Costa e ao Professor André CASTRO CARVALHO, pelas valorosas contribuições ao aprimoramento desta pesquisa, e por proporcionarem verdadeiro momento de aprendizado multidisciplinar, quando da arguição de qualificação. 
À International Anti-Corruption Academy (IACA), pela concessão de bolsa integral em sua Regional Summer Academy, e que proporcionou, quase ao final desta dissertação, ampliar a visão global do fenômeno corruptivo.

Aos amigos forjados no Largo de São Francisco WiLson Accioli de BARRos FiLHO e MARIANA CARNAES FerReira, por todos os momentos de compartilhamento de felicidade e angústia, ao longo desses anos. Foi um privilégio desfrutar da amizade de vocês.

Àqueles que a Pontifícia Universidade Católica de São Paulo produziu de melhor, os amigos de todas as horas André CAmargo Galvão, Gabriel Stornioli Lemos, José Mário Neves David, Leonardo Nusman, Luis Augusto Morosini, Maurício Pereira Colonna Romano e Victor Rios Simplício. Obrigado pela compreensão da (quase sempre) ausência indesejada.

Aos meus pais, Fátima Maria Gnecco e Rainer Marinho da Costa, e aos meus sogros, Maria JosÉ GonÇalves Guerini e EduARDo HenRIQUe GuerinI, por todo o apoio nos momentos difíceis ao longo da jornada. À minha amada avó YARA MARIA MARINHO DA COSTA (in memoriam) que desde cedo estimulou, por seu exemplo, a prática acadêmica; sei que de onde estiver, ilumina minha trajetória.

Por fim, à minha doce CAROLINE GonÇALVES GuERINI, retrato de companheirismo, afeto, e paciência, que por diversas vezes abdicou de suas prioridades em prol deste trabalho, e a quem devo seus melhores lampejos. Todo o tempo que deveria ser exclusivo seu, e não foi, resultou nesta dissertação. Obrigado por existir. 
"[O] jurista não pode esperar por um Direito ideal. Ele deve trabalhar com o Direito existente, em busca de soluções melhores."

(STARCK, Boris. Domaine et fondament de la responsabilité sans faute. Revue Trimestrelle de Droit Civil. P.477-515, 1958.) 


\section{RESUMO}

\section{MARINHO DA COSTA, Yahn Rainer Gnecco. Delineamentos sobre a responsabilidade}

objetiva das pessoas jurídicas por atos de corrupção no Brasil. 2019. 333 p. Dissertação

(Mestrado em Direito do Estado) - Faculdade de Direito, Universidade de São Paulo, São

Paulo, 2019.

Com a finalidade de lançar luzes sobre a responsabilidade administrativa objetiva inaugurada, no ordenamento jurídico brasileiro, pela edição da Lei Federal n ${ }^{\circ} 12.846$, de $1^{\circ}$ de agosto de 2013 ("Lei Anticorrupção"), o presente trabalho busca investigar, de modo dedutivo analítico, a conformidade de tal instituto às esferas de responsabilização delineadas pela Constituição Federal, dentro de uma perspectiva garantista da perquirição de culpa conferida pelos preceitos do Direito Administrativo Sancionador. Para tanto, parte-se de uma análise evolutiva do instituto da responsabilidade nas esferas cível e penal, cotejando suas respectivas modalidades e especificidades à responsabilidade administrativa, e da eventual aderência das disposições contidas em diplomas internacionais anticorrupção às normas brasileiras de responsabilização de pessoas jurídicas. Sendo a moralidade pública um bem jurídico fim, que enfeixa um sistema de responsabilização próprio, instrumentalizado pela Lei Federal $\mathrm{n}^{\circ}$ 8.429, de 02.06.1992 ("Lei de Improbidade Administrativa" e pela Lei Anticorrupção - ambas aplicáveis às pessoas jurídicas -, partir-se-á de uma aproximação com os institutos desenvolvidos pelo Direito Penal (notadamente em uma acepção de corte pós-finalista), afim de contrapor o instituto da responsabilidade às características precípuas das pessoas jurídicas (ausência de animus próprio), buscando-se um conceito de culpabilidade corporativa capaz de instrumentalizar sua responsabilização no âmbito de processos de responsabilização em matéria sancionatória de Direito Administrativo. O resultado da pesquisa permite concluir que, a despeito de estabelecer uma suposta modalidade objetiva à responsabilidade administrativa de pessoas jurídicas pela prática de atos de corrupção, a melhor interpretação da Lei Anticorrupção exige sua compatibilização ao princípio da culpabilidade, sem descurar, todavia, da efetivação dos processos de responsabilização por ela estabelecidos. O processo de responsabilização das pessoas jurídicas por atos de corrupção deverá, outrossim, ser dirigido na perquirição de elementos objetivos de culpa, externalizados pela pessoa jurídica na sociedade, cabendo o apontamento de sugestões de melhoria na relação de fiscalização e sancionamento das pessoas jurídicas que com o Estado se relacionem.

Palavras-chave: Corrupção, Responsabilidade administrativa, Responsabilidade objetiva, Compliance, Culpabilidade 


\begin{abstract}
MARINHO DA COSTA, Yahn Rainer Gnecco. Guidelines on the strict liability of legal entities for corruption's acts in Brazil. 2019. 333 p. Thesis (Master in Public Law) Faculty of Law, University of São Paulo, São Paulo, 2019.

In order to shed light on the administrative strict liability inaugurated in the Brazilian legal order by the Federal Law No. 12,846, of August 1th, 2013 ("Anti-Corruption Law"), this thesis seeks to investigate, in an analytical deductive view, the conformity of such institute to the spheres of accountability outlined by the Brazilian Federal Constitution, within a guaranteeing perspective of the investigation of guilt conferred by the precepts of the Sanctioning Administrative Law. Therefore, it starts from an evolutionary analysis of the institute of liability in the civil and criminal spheres, comparing its respective modalities and specificities to the administrative liability, and the eventual adherence of the provisions contained in international anti-corruption laws to the Brazilian norms of legal entities liabilities. Since public morality is a protected legal interest, which embodies a system of self-accountability instrumentalized by Federal Law No. 8.429, of June 2th, 1992, and the Anti-Corruption Law - both applicable to legal entities -, approaching the institutes developed by Criminal Law (notably in a sense of post-finalist), in order to oppose the institute of responsibility to the main characteristics of legal entities (absence of animus itself), seeking a concept of culpability able to instrumentalize its accountability in the context of administrative law sanctioning processes. The result of the research shows that, despite establishing a supposed strict administrative liability of legal entities for the practice of corruption acts, the best interpretation of the Anti-Corruption Law requires its compatibility with the principle of guilt, however, without neglecting the implementation of the liability processes established by it. The sanctioning process of legal entities liable for corruption acts should also be directed towards the investigation of objective elements of guilt, externalized by the legal entity in society, with the suggestion of improving the relationship of supervision and sanctioning of legal entities that maintain a private public relationship with the Government.
\end{abstract}

Keywords: Corruption, administrative liability, strict liability, compliance, culpability 


\section{LISTA DE ABREVIATURAS E SIGLAS}

AFA

CGU

CICC

CPI

DOJ

FCPA

MESICIC

MPF

OCDE

OEA

ONU

PAR

SCPC

SEC

SFO

SUPERSOCIEDADES

TCU

UBKA

UNCAC
Agence Française Anticorruption

Controladoria Geral da União

Convenção Interamericana Contra a Corrupção

Corruption Perception Index

Department of Justice dos Estados Unidos da América

Foreign Corrupt Practices Act

Mecanismo de Acompanhamento da Implementação da CICC

Ministério Público Federal

Organização para Cooperação e Desenvolvimento Econômico

Organização dos Estados Americanos

Organização das Nações Unidas

Processo Administrativo de Responsabilização da Lei Anticorrupção

Service Central de Prèvention de la Corruption da França

Securities and Exchange Commission dos Estados Unidos da América

Serious Fraud Office do Reino Unido

Superintendencia de Sociedades da Colômbia

Tribunal de Contas da União

United Kingdom Bribery Act

Convenção das Nações Unidas Contra a Corrupção 


\section{LISTA DE TABELAS}

TABELA I - PRINCIPAIS CONVENÇÕES INTERNACIONAIS CONTRA A CORRUPÇÃO................. 38

TABELA II - PRIMEIRA RodAdA DE AVALIAÇÃO - MESICIC 43

TABELA III - SEgUndA RodAdA DE AVALIAÇÃO - MESICIC 45

TABELA IV - TERCEIRA RODADA DE AVALIAÇÃO - MESICIC 46

TABELA V - PRINCIPAIS RECOMENDAÇÕES DA FASE I - WORKING GROUP ON BRIBERY ...... 53

TABELA VI - PRINCIPAIS RECOMENDAÇÕES DA FASE II - WORKING GROUP ON BRIBERY ... 54

TABELA VII - PrinciPAis RECOMENDAÇÕES DA FASE III - WORKING GROUP ON BRIBERY. 55

TABELA VIII - PRINCIPAIS TEORIAS DA CULPABILIDADE PRÓPRIA DA PESSOA JURÍDICA... 178

TABELA IX - PRINCÍPIOS NORTEADORES DO DiREITO ADMINISTRATIVO SANCIONADOR ... 219 


\section{SUMÁRIO}

INTRODUÇÃO. 15

1 MATRIZ CONSTITUCIONAL DE RESPONSABILIDADE POR ATOS DE CORRUPÇÃO - MICROSSISTEMA DE TUTELA DA MORALIDADE PÚBLICA

1.1 Noção preliminar: o conceito de "atos de corrupção" adotado no presente estudo

1.2 Uma primeira aproximação: o cenário internacional de combate à corrupção e o

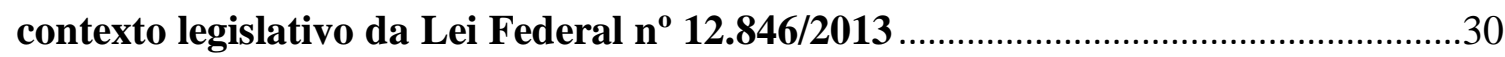

1.2.1 As convenções internacionais contra a corrupção ....................................... 34

1.2.2.1 Convenção Interamericana contra a Corrupção (Convenção de Caracas OEA, 1996)

1.2.2.2 Convenção sobre o Combate da Corrupção de Funcionários Públicos

Estrangeiros em Transações Internacionais (Convenção de Paris - OCDE, 1997) . 48

1.2.2.3 Convenção das Nações Unidas contra a Corrupção (Convenção de Mérida ONU, 2003) .58

1.2.2 Escorço legislativo para fins de implementação de uma política anticorrupção no Brasil.

1.30 artigo 37, caput, da Constituição Federal: a moralidade pública como bem jurídico tutelado de interesse transindividual. .68

1.3.1 A moralidade no interior do Direito: o viés da integridade. .79

1.4 A trajetória de responsabilização das pessoas jurídicas autorizada pela Constituição Federal .88

1.5 Síntese parcial do capítulo .96

\section{A RESPONSABILIZAÇÃO DA PESSOA JURÍDICA} 99

2.1 Enquadramento da pessoa jurídica para fins de responsabilização 101

2.2 A responsabilidade da pessoa jurídica pela (i)licitude de sua conduta.

2.2.1 A responsabilidade subjetiva e sua imputação. 116

2.2.1.1 A culpa como pressuposto da responsabilidade subjetiva 119

2.2.1.2 A imputação de responsabilidade por fato de terceiro 120 
2.3.1 A responsabilidade civil objetiva ...................................................... 130

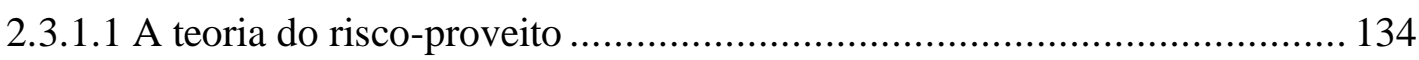

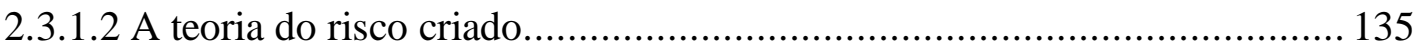

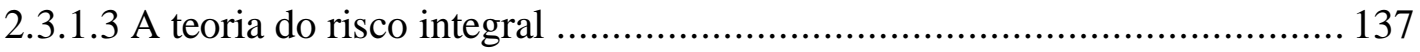

2.3.1.4 A (teoria da) responsabilidade civil objetiva do Estado ......................... 138

2.3.2 A responsabilidade penal (objetiva?) ..................................................... 144

2.3.3 A responsabilidade administrativa objetiva .......................................... 151

2.4 As espécies de sanção e seus efeitos para a esfera de responsabilização ............ 156

2.4.1 A sanção administrativa e a finalidade sancionatória no âmbito da

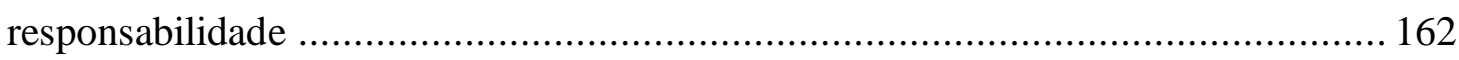

$2.5 \mathrm{O}$ injusto na responsabilidade da pessoa jurídica ............................................ 174

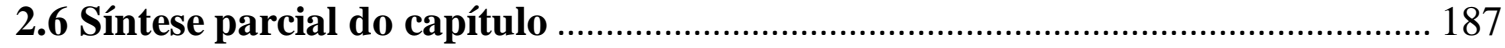

3 RESPONSABILIDADE ADMINISTRATIVA ANTICORRUPÇÃO: UMA MODALIDADE DE RESPONSABILIDADE OBJETIVA? ................................ 191

3.1 As experiências internacionais na esfera de responsabilização das pessoas

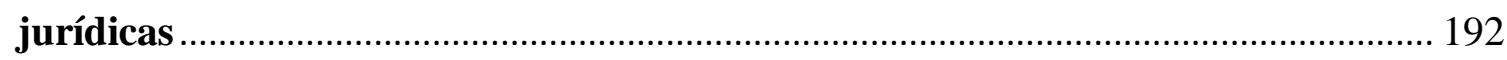

3.2 A Responsabilidade no Direito Administrativo Sancionador Brasileiro ............ 210

3.2.1 Os princípios norteadores da responsabilização administrativa no Brasil ....... 215

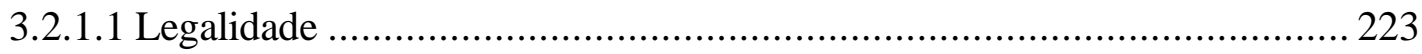

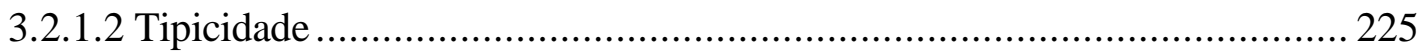

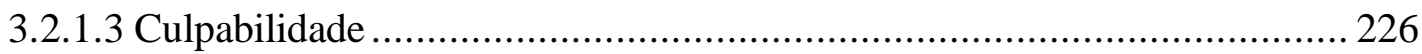

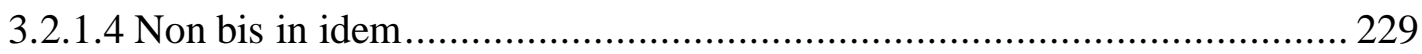

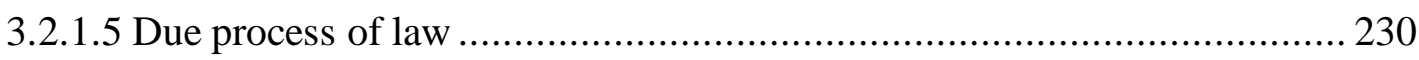

3.2.2 A responsabilidade presente na Lei de Improbidade Administrativa.............. 233

3.2.3 Os contornos da responsabilidade veiculada pela Lei Anticorrupção.............. 237

3.3 A (In)compatibilidade da responsabilidade objetiva aos princípios do Direito

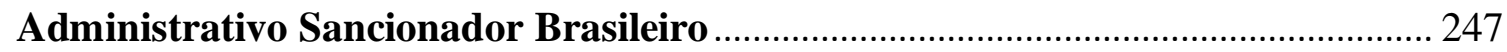

3.4 O mito da responsabilidade objetiva no âmbito da Lei Anticorrupção ............ 249 3.5 Culpabilidade corporativa e a Lei Anticorrupção: sugestões para melhor aplicação da responsabilidade administrativa anticorrupção ................................. 257

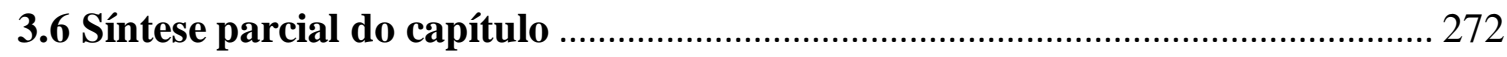


CONCLUSÕES.

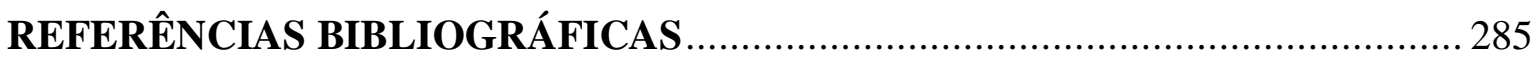

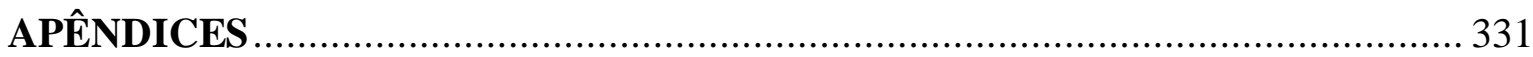




\section{INTRODUÇÃO}

A Lei Federal $n^{\circ} 12.846$, de $1^{\circ}$ de agosto de 2013, popularmente conhecida como Lei Anticorrupção, Lei da Empresa Limpa ou Lei de Probidade Empresarial ${ }^{1}$, se insere no cenário de mudanças estruturais das instituições do Estado reivindicadas pela sociedade após os inúmeros escândalos de corrupção política descortinados nas últimas décadas².

Decorrente do Projeto de Lei $\mathrm{n}^{\mathrm{o}}$ 6.826/2010, de iniciativa da Presidência da República e gestado na Controladoria Geral da União ("CGU”), a Lei buscou, inicialmente, adequar a legislação pátria às convenções internacionais já ratificadas pelo Brasil ${ }^{3}$; todavia, em razão do contexto político vivenciado pelo país, notadamente após as manifestações sociais ocorridas ao longo do mês de junho de 2013, se tornou importante instrumento à disposição da Administração Pública para o combate à prática de atos de corrupção.

Com a finalidade de reforçar a tutela jurídica da moralidade pública (tornando-a sustentáculo de uma Administração Pública hígida), a Lei descortinou a existência de um microssistema de moralidade pública formado por um conjunto de normas nacionais e internacionais.

Em razão de sua célere tramitação, decorrente do momento político vivenciado em seu processo legislativo ${ }^{4}$, uma série de questionamentos acerca de sua aplicabilidade e operacionalização foram invariavelmente aventados após o início de sua vigência, dos quais

\footnotetext{
${ }^{1}$ A despeito das demais denominações, em razão da maior popularização do termo "Lei Anticorrupção" no âmbito doutrinário e da Administração Púbica, adotar-se-á amplamente no presente estudo, referido termo.

${ }^{2}$ Importante ressaltar que o movimento de avanço na pauta legislativa de combate à corrupção é, historicamente, relacionado aos momentos de grande fragilidade das instituições políticas. Cite-se ilustrativamente a Lei Federal no 8.429 de 02 de junho de 1992 ("Lei de Improbidade Administrativa"), promulgada na esteira do impeachment do ex-presidente Fernando Collor, a Lei Complementar Federal no ${ }^{\circ} 135$, de 04 de junho de 2010 ("Lei da Ficha Limpa"), cuja iniciativa popular é decorrente de um movimento de insatisfação popular aos diversos casos de corrupção política ocorrido no início dos anos 2000, e a Lei Federal n 13.303 , de 30 de junho de 2016 ("Lei das Empresas Estatais"), promulgada como suposta "solução" aos escândalos de corrupção originados em nomeações políticas para cargos em empresas estatais.

${ }^{3}$ Convenção sobre o combate da corrupção de funcionários públicos estrangeiros em transações comerciais internacionais (OCDE - 1997), ratificada por meio do Decreto Federal $n^{\circ}$ 3.678/2000; Convenção Interamericana contra a Corrupção (OEA - 1996), ratificada por meio do Decreto Federal no 4.410/2002; e Convenção das Naçães Unidas contra a Corrupção (ONU - 2003), ratificada por meio do Decreto Federal $n^{\circ}$ $5.687 / 2006$.

${ }^{4}$ A título de ilustração aponte-se que a Câmara dos Deputados, a despeito de ter ouvido grandes nomes do direito quando da tramitação do Projeto de Lei n ${ }^{\circ}$ 6.826/2010, "engavetou" o Projeto de Lei de 13.06.2012 à 23.04.2013 - ou seja, 314 (trezentos e quatorze) dias -, arrefecendo qualquer maior discussão acerca da temática. Contudo, impulsionada pela "percepção de impunidade" propalada pela população, e pelo descontentamento popular, a Câmara encaminhou o Projeto de Lei ao Senado Federal, como uma resposta política aos anseios da população, em 19.06.2013. O Senado Federal, por sua vez, aprovou a redação final do Projeto de Lei em regime de urgência, em exatos 15 (quinze) dias, sem ter realizado qualquer discussão aprofundada acerca da temática.
} 
sobressai-se a figura da responsabilidade objetiva da pessoa jurídica (notadamente em razão de uma suposta ocorrência de "fraude de etiquetas", entre o ilícito penal e o administrativo).

Diante da quimera criada pelo legislador, por conseguinte, tomaram à frente das discussões do texto normativo os estudiosos do Direito Penal ${ }^{5}$ e do Direito Empresarial ${ }^{6}$, os quais reclamaram para si a noção de "prática corruptiva" baseada nas respectivas práxis.

Somente após a edição da Medida Provisória n 703, de 18 de dezembro de 2015 — já decaída e sem aplicabilidade no momento —, que disciplinou aspectos controversos da Lei, e que pretendeu realizar importantes modificações na Lei Federal no 8.429, de 2 de junho de 1992 ("Lei de Improbidade Administrativa")", é que a comunidade administrativista avocou para si a responsabilidade de analisar a referida Lei, restringindose, fortemente e de modo equivocado, à figura do Acordo de Leniência ${ }^{8} 9$.

Desbordando-se do digno encaminhamento proposto pelas demais áreas do Direito - e igualmente das análises realizadas, especificamente, sobre eventuais inconsistências da Medida Provisória no 703/2015 —, a análise da Lei Anticorrupção sob a ótica do Direito Administrativo demanda, com a devida vênia, maior prudência do estudioso, dado os contornos estabelecidos pela Constituição Federal, e pelo Direito Administrativo Sancionador.

Aspectos como (i) a existência, ou não, de matriz autônoma da responsabilidade administrativa pela prática de atos de corrupção, (ii) a compatibilidade da responsabilização objetiva dos ilícitos praticados pelas pessoas jurídicas ao Direito Sancionador, (iii) a coexistência harmônica, ou não, da Lei Anticorrupção e da Lei de Improbidade Administrativa, como normas integrantes de um novo microssistema de tutela da moralidade pública, e (iv) a compatibilidade do processo sancionador estabelecido com os preceitos do Direito Administrativo Sancionador, demanda uma acurada análise do estudioso,

\footnotetext{
${ }^{5}$ Exempli gratia, cite-se GUILHERME DE SOUZA NUCCI (Corrupção e Anticorrupção. Rio de Janeiro: Forense, 2015), VICENTE GRECCO ( $O$ combate à corrupção e comentários à lei de responsabilidade de pessoas jurídicas. São Paulo: Saraiva: 2015).

${ }^{6}$ Notadamente MODESTO CARVALHOSA (Considerações sobre a lei anticorrupção das pessoas jurídicas. São Paulo: Revista dos Tribunais, 2015).

${ }^{7}$ Cite-se o artigo $2^{\circ}$, I, da Medida Provisória n ${ }^{\circ} 703 / 2015$, que pretendeu revogar o artigo 17, $\S 1^{\circ}$, da Lei Federal $\mathrm{n}^{\mathrm{o}} 8.429$, de 02 de junho de 1992, permitindo, portanto, a realização de transações civis no bojo de processos de improbidade administrativa.

${ }^{8}$ Por todos, cite-se FÁBIO MEDINA OSÓRIO.

${ }^{9}$ A despeito de administrativistas de nome, tais como Maria Sylvia Zanella di Pietro, Celso Antônio Bandeira de Mello, MarÇal Justen Filho, e Romeu Felipe Bacellar Filho, terem participado - em 2011 - da tramitação do Projeto de Lei n ${ }^{\circ}$ 6.826/2010 na Câmara dos Deputados, as discussões acerca do texto legislativo não extravasaram para a academia até sua promulgação.
} 
proporcionando (caso assim seja) uma acomodação da Lei Anticorrupção ao restante do sistema jurídico brasileiro.

De igual modo, por integrar o processo de evolução da própria teoria da responsabilidade - que caminha da responsabilização decorrente da prática de ato culposo, para a garantia de reparação integral ex lege - faz-se importante analisar o modelo de responsabilização inaugurado pela Lei Anticorrupção sob a ótica das teorias já desenvolvidas no Direito brasileiro, notadamente pelo Direito Civil com viés consumerista e ambiental, e pelo Direito Penal, onde a responsabilidade objetiva já é (há muito) abordada.

Discutir a temática da responsabilidade objetiva das pessoas jurídicas pela prática de atos de corrupção, no contexto político-social vivenciado no Brasil ao longo dos últimos anos, não se mostra uma tarefa fácil. Os recentes, e reiterados, escândalos políticos vivenciados na justiça brasileira ${ }^{10}$ projetaram na população uma carga de pânico moral ${ }^{11}$, que rotulou negativamente a atividade pública - notadamente sua interface com a iniciativa privada - , colocando em questão a credibilidade daqueles que com ela se relacionam. Tal pensamento igualmente tem se expandido para parcela da academia, que vislumbra em eventuais discordâncias jurídicas de teses de controle pro societate verdadeiras tergiversações em prol de determinados interesses (políticos ou econômicos).

A forma como a sociedade passa a receber a lesividade das condutas praticadas por seus agentes, ou ainda a forma com a qual passa a observá-los, propulsiona uma produção legislativa na tentativa de reaver a higidez da Administração Pública e blindagem institucional dos setores econômicos. As "soluções miraculosas" para a crise no sistema punitivo, no mais das vezes, perpassam por tumultuosas inovações legislativas ${ }^{12}$ voltadas ao recrudescimento da resposta Estatal.

\footnotetext{
${ }^{10}$ Dos quais podemos apontar recentemente a chamada "Máfia do ISS" no Município de São Paulo, e os desdobramentos trazidos à tona por meio das operações "Porto Seguro" - que demonstrou um processo sistemático de tráfico de influência no Governo Federal - e "Lava-Jato" - que escancarou o aparelhamento de empresas públicas, objetivado para a prática de atos corruptivos - da Polícia Federal.

${ }^{11}$ Tradução livre do termo cunhado por STANLEY COHEN, definido como situações em que "uma condição, episódio, pessoa ou grupo de pessoas emerge para ser definido como uma ameaça aos valores e interesses sociais" in: COHEN, Stanley. Folk Devils and Moral Panics. $3^{a}$ Edição. Oxford: M. Robertson, 1980.P. 4.

${ }^{12}$ Cf. FÁBIo Medina OsóRIO (Direito Administrativo Sancionador. $5^{\mathrm{a}}$ Ed. São Paulo: RT, 2015), in verbis: "Os sintomas ou causas dessa crise de qualidade e eficiência do sistema punitivo, incluindo todos seus discursos de gestão, marcadamente na seara penal, são complexos, múltiplos e enigmáticos, tanto que raramente, ou nunca, são abordados pelos teóricos da área. É como se não existissem tais patologias institucionais. As causas, e até mesmo a extensão dessas verdadeiras doenças endêmicas, envolvem mistérios institucionais indecifráveis. Por isso, sempre que eclodem escândalos de impunidade, emergem soluções puramente normativas, com reformas pontuais na legislação penal ou noutras searas, como na área da improbidade. A culpa sempre tem um nome: o legislador. Mude-se a legislação, porque os operadores jurídicos apenas cumprem o que está previamente descrito nas leis. Reforme-se a legislação punitiva ou a legislação processual, não importa, a responsabilidade é do legislador. (P. 56)
} 
No presente caso, principalmente em razão da influência midiática, a opção adotada buscou, por meio de severas sanções administrativas, não apenas reparar os danos (patrimoniais ou morais) ocorridos - inerentes à responsabilidade civil -, mas induzir a conduta dos administrados, pessoas físicas e jurídicas, a prevenirem sua ocorrência, pelo exemplo da sanção exemplar. Objetiva a Lei Federal n 12.846/2013, portanto, tornar o Direito Administrativo ferramenta de controle de condutas mais célere, atendendo-se às expectativas punitivas afloradas da sociedade brasileira.

De se frisar, contudo, que apesar do anseio popular a que veio atender, a Lei Anticorrupção "foi elaborada com o fito de primar pela celeridade na punição, o que [por sua vez] não significa fazer justiça" ${ }^{13}$, conforme bem apontado por GUILHERME DE SOUSA NUCCI.

A ausência de valoração do elemento subjetivo na prática da conduta, embora assim já ocorresse nos primórdios do Direito Romano ${ }^{14}$, desaparece dos ordenamentos jurídicos após a vigência da lex aquilia, justamente em razão do potencial arbitrário de sua aplicação ${ }^{15}$.

Somente com a proliferação, generalização e abstração dos riscos, ocorrida após a Revolução Industrial, é que, por meio do aperfeiçoamento das ideias de RAYMOND SALEILLES e LOUIS JOSSERAND, a responsabilização novamente se desvinculará da noção de culpa, passando a própria "fôrça, a iniciativa, a ação, (...) ser[em] por si mesmas geradoras de responsabilidade" 16 .

Há se refletir, todavia, que "aplicar ao direito punitivo uma imputação automática, que nada esclarece sobre a reprovabilidade que justificaria a punição da pessoa jurídica, pode ser algo de difícil conciliação com as garantias constitucionais que se aplicam a qualquer

\footnotetext{
${ }^{13}$ NUCCI, Guilherme de Souza. Corrupção e Anticorrupção. Rio de Janeiro: Forense, 2015. P. 90

${ }^{14}$ A inferência é de SERGIO CAVALIERI FILHO, in verbis: "Há quem sustente que no Direito Romano arcaico a responsabilidade civil era puramente objetiva, admitindo inclusive casos de responsabilidade por ato lícito. A culpa, como elemento integrante da responsabilidade, só teria surgido com a Lex Aquilia. Seja como for, o certo é que a responsabilidade objetiva ficou afastada por muito tempo, caiu em desuso até os tempos modernos, quando ocorreu o seu ressurgimento." (Programa de Responsabilidade Civil. 10a Ed. São Paulo: Atlas, 2012, P. 151).

${ }^{15}$ Mauro Sérgio dos Santos, ao analisar a responsabilidade extracontratual no Direito Romano assevera que, até o advento da Lex Aquilia, "mesmo ausente o dolo ou a culpa, era possível a aplicação de sanção a alguém, caso restasse comprovada a prática de conduta ilícita causadora de dano. Evidentemente que a desconsideração do elemento subjetivo da conduta gerava situações injustas e desproporcionais." ("Responsabilidade civil extracontratual no direito romano: análise comparativa entre os requisitos exigidos pelos romanos e os elementos da responsabilidade civil atualmente existentes”. In Revista Direito em Ação. Brasília, v. 10. N.1, 2013).

${ }^{16}$ JOSSERAND, Louis. Evolução da responsabilidade civil. In. Revista Forense, V. LXXXVI, Fascículo 454. Rio de Janeiro: Forense, 1941. P. 548, 559, P. 557.
} 
exercício de poder punitivo estatal" 17 . Não entendemos salutar, portanto, a postura passiva de adotar pura e simplesmente, no âmbito punitivo-sancionador administrativo, soluções criadas (a partir de lógicas próprias) em outras áreas do saber ou culturas.

Considerando que a Lei Anticorrupção se insere no âmbito de responsabilização promovido pelo Direito Administrativo Sancionador, imperioso desbordar-se da mera análise das teorias advindas do direito privado (e que naquela esfera do saber são justificáveis), ou da eventual necessidade de incorporação no ordenamento jurídico brasileiro de "melhores práticas" internacionais.

Se na responsabilidade civil objetiva a pessoa física ou jurídica se torna verdadeira "seguradora" ex lege dos riscos que cria a terceiros (cingindo-se à restauração do dano, ou à sua reparação material), faz-se necessário meditar acerca das vantagens, ou prejuízos, decorrentes da não-perquirição da vontade do agente em âmbito sancionatório e, notadamente, na responsabilidade administrativa.

Decantado o contexto de exacerbação punitivista ${ }^{18}$, o presente trabalho se destina a aprofundar os debates acerca da inovação legislativa da Lei Anticorrupção à luz da Constituição Federal e dos avanços realizados no Direito Civil e no Direito Penal em sede de responsabilização das pessoas jurídicas. Pretende-se, com isso, obter um viés de análise próprio do Direito Administrativo Sancionador à responsabilidade administrativa objetiva, priorizando um equilíbrio harmonioso entre as expectativas sociais da "responsabilidade" e da "liberdade" das pessoas jurídicas.

A estrutura do presente trabalho encontra-se ordenada em três capítulos, distribuídos de acordo com a temática a ser abordada, bem como de um capítulo destinado às conclusões finais.

De forma detalhada, com o vetor de criar os alicerces para a discussão travada na dissertação, o primeiro capítulo, intitulado Matriz constitucional de responsabilidade por atos de corrupção-Microssistema de tutela da moralidade pública, atenderá a três aspectos essenciais. O primeiro, franquear ao leitor noção preliminar sobre o qual sustenta-se todo o presente estudo, o conceito de corrupção adotado pelo autor (subseção 1.1).

\footnotetext{
${ }^{17}$ FRAZÃO, Ana. "Programas de compliance e critérios de responsabilização de pessoas jurídicas por ilícios administrativos" In ROSSETTI, Maristela Abla; PITTA, Andre Grunspun (Coords). Governança corporativa. Avanços e retrocessos. São Paulo: Quartier Latin, 2017. P. 23, 58. P. 31, 32.

18 A Lei Anticorrupção, nesse passo, reflete a busca incessante do cidadão pela honestidade na administração pública. A Lei proporcionou, destarte, nos dizeres de SÉRGIO MURILO MUNHOZ FONTANA (apud NUCCI, Guilherme de Souza. Corrupção e Anticorrupção. Rio de Janeiro: Forense, 2015. P. 86), “uma coloração de justiça e de direito à vontade do povo".
} 
Por ter sido fortemente influenciada pelo cenário global de combate à prática corruptiva, o segundo aspecto a ser analisado será o contexto de promulgação da Lei Anticorrupção, mediante investigação dos três principais instrumentos normativos internacionais (a Convenção de Caracas, a Convenção de Paris e a Convenção de Mérida) e, principalmente das obrigações a que o Brasil tenha, efetivamente, se autovinculado (seção 1.2).

À luz da necessidade de "tomar todas as medidas necessárias ao estabelecimento das responsabilidades de pessoas jurídicas" 19 de acordo com os princípios jurídicos próprios do ordenamento jurídico brasileiro - prevista no art. $2^{\circ}$ da Convenção de Paris -, propõe-se a partir da seção 1.3. analisar o terceiro aspecto essencial para compreensão da dissertação. Partindo-se do artigo 37, caput, da Constituição Federal, propor-se-á o reconhecimento da moralidade pública como bem jurídico imaterial, tutelado por um microssistema de tutela da moralidade pública, subdividido na tutela da probidade ( $\operatorname{art.} 37, \S 4^{\circ}$ ), e na tutela da integridade (art. 37, caput), no qual se conformariam as disposições normativas veiculadas pela Lei de Improbidade Administrativa, e pela Lei Anticorrupção. À luz de tal teorização, buscar-se-á, apontar o modelo de responsabilidade constitucionalmente previsto em face de ilícitos praticados, ou danos ocasionados, por tais entes personalizados (seção 1.4).

O segundo capítulo, nomeado A responsabilização da pessoa jurídica, é dedicado ao estudo dos diversos modelos de responsabilidade admitidos no ordenamento jurídico.

Após a explanação do conceito e da natureza jurídica das pessoas jurídicas (seção 2.1) adotados na presente dissertação - noções instrumentais para sedimentação do objeto da pesquisa -, desbravar-se-ão os caminhos percorridos entre o surgimento das teorias de responsabilidade subjetiva (seção 2.2) às modalidades de responsabilidade objetiva (seção 2.3). Intenciona-se, com isso, destacar as respectivas causas justificadoras e finalidades precípuas de cada modelo, apresentando, a seu turno, as espécies de sanção, as correspondentes consequências jurídicas e, por fim, a finalidade sancionatória da sanção administrativa (seção 2.4). A seção 2.5., por sua vez, se dedicará à compreensão da caracterização do injusto na esfera de responsabilização das pessoas jurídicas.

Em breve síntese, enquanto a seção 2.1 abordará por meio dos quatro principais grupamentos teóricos, a tormentosa discussão quanto à natureza, e a eventual existência de uma vontade, da pessoa jurídica, a seção 2.2 aproximará o leitor das teorias da

\footnotetext{
${ }^{19}$ Art. $2^{\circ}$ da Convenção sobre o Combate da Corrupção de Funcionários Públicos Estrangeiros em Transações Internacionais, promulgada por meio do Decreto Federal n 3.678, de 30 de novembro de 2000.
} 
responsabilidade civil - berço da noção de responsabilidade jurídica -, abordando-se a responsabilidade subjetiva e sua mais relevante teoria de transição, a imputação por fato de terceiro, contextualizando-as em seus respectivos momentos históricos. Ato contínuo, a seção 2.3 dedicar-se-á à evolução da teoria do risco, e ao deslocamento do foco central da responsabilidade, priorizando-se a proteção às vítimas de riscos abstratos, apresentando as modalidades de risco proveito, risco criado e risco integral. Serão igualmente versadas a responsabilidade penal objetiva, cuja previsão nos art. $173, \S 5$, e art. $225, \S 3^{\circ}$, da Constituição Federal, ainda não se encontra pacificada na doutrina penalista, e eventual existência da responsabilidade administrativa objetiva.

A seção 2.4, por sua vez, será destinada à investigação das finalidades (ressarcitória, retributiva e preventiva) sancionatórias em cada esfera de responsabilidade. Ao final, a seção 2.5 se valerá das teorias desenvolvidas pelo Direito Penal para apresentar visões inovadoras, notadamente pós-finalistas, para compreensão do injusto típico e da culpabilidade adequada à pessoa jurídica, atrelada precipuamente à identificação de fatores externalizados pela pessoa jurídica em seu seio social.

O terceiro capítulo, intitulado Responsabilidade administrativa anticorrupção: uma modalidade de responsabilidade objetiva?, por sua vez, centra a preocupação do estudo na responsabilidade da pessoa jurídica pela prática de atos de corrupção, e seu cotejo com os ditames do Direito Administrativo Sancionador brasileiro. Inicialmente, serão apresentadas as experiências estrangeiras mais bem-sucedidas de responsabilização das pessoas jurídicas (seção 3.1), a serem utilizadas como modelos referenciais com soluções passíveis de ser adaptadas ao ordenamento jurídico brasileiro. Buscar-se-á, ato contínuo, identificar o locus da responsabilidade objetiva no âmbito do Direito Administrativo Sancionador brasileiro, trazendo à tona os princípios norteadores da responsabilização por infrações a normas de Direito Administrativo (seção 3.2.1), caracterizando os modelos de responsabilidade presentes nas normas integrantes do microssistema de tutela da moralidade pública (seções 3.2.2 e 3.2.3), e cotejando, de modo especialmente crítico, o modelo de responsabilidade veiculada pela Lei Anticorrupção (responsabilidade administrativa objetiva) a tal referencial constitucional (seções 3.3 e 3.4).

Ao final, objetiva-se demonstrar os contornos jurídicos possíveis de uma eventual responsabilidade administrativa objetiva, apresentando-se sugestões infralegais para sua melhor aplicação no cenário normativo brasileiro (seção 3.5). 


\section{CONCLUSÕES}

O instituto da responsabilidade objetiva possui contornos próprios e advindos de sua trajetória de criação e implementação em cada ordenamento jurídico; não há, assim, uma única responsabilidade objetiva, aplicável de modo uniforme a qualquer violação ao Direito posto de qualquer Estado.

A responsabilidade objetiva é, portanto, a responsabilidade objetiva e suas circunstâncias $^{928}$.

Proposta sob a justificativa de incorporar, no Direito brasileiro, normas internacionais convencionadas e aderidas pelo Brasil ao longo das décadas de 1990 e 2000, a responsabilidade objetiva das pessoas jurídicas se torna, no iter de uma peculiar tramitação legislativa, nova "solução miraculosa" para a crise no sistema punitivo-sancionador brasileiro.

Os sentimentos de pânico moral, de indignação com a classe política, e de impunidade existente na sociedade, direcionou a obrigação convencionada pelo Brasil - outrora buscar responsabilizar efetivamente as pessoas jurídicas envolvidas em atos de corrupção, de acordo com seus princípios próprios, nos termos das Convenções de Paris (1997) e de Mérida (2003) - ao caminho da implementação de uma responsabilidade administrativa objetiva das pessoas jurídicas, sem, contudo, realizar uma profunda e ampla discussão na comunidade acadêmica e, tampouco, utilizar a melhor técnica legislativa para, de um lado, acomodar modelos estrangeiros à legislação nacional, e por outro, trazer claramente todos os elementos da responsabilidade para sua melhor compreensão.

O presente trabalho objetivou, a partir da lógica própria do Direito Administrativo Sancionador, analisar a inovação legislativa trazida pela Lei Anticorrupção, priorizando um equilíbrio harmonioso entre (i) as expectativas sociais da "responsabilidade" e da "liberdade" das pessoas jurídicas, e (ii) a titanomaquia do "eficientismo" versus "garantismo" nos processos punitivos, em uma trajetória contínua de acomodação da Lei ao ordenamento jurídico brasileiro.

A responsabilização no Direito brasileiro - qualquer que seja seu âmbito de incidência ou modalidade adotada - deve observar os termos expostos na Constituição Federal, e os sistemas de responsabilização nela presentes, enfeixados a partir de bens jurídicos

\footnotetext{
928 Em paráfrase da clássica lição de JOSÉ ORTEGA Y GASSET ("o homem é o homem e suas circunstâncias"), por meio da qual sintetizou-se que o ser humano apenas pode ser compreendido à partir da análise simultânea de sua unidade e de seu entorno
} 
específicos; a internalização das disposições de Convenções Internacionais, por óbvio, também não poderá dela se afastar.

A trajetória de internalização da responsabilização das pessoas jurídicas sugerida pelas normas de Direito Internacional deve passar, assim, necessariamente, pelos sistemas de responsabilização pré-existentes e pelas normas constitucionais e princípios do ordenamento jurídico nacional. No caso, defendemos que o modo como os dispositivos legais foram redigidos - não se restringindo, por exemplo, as sanções à defesa da ordem econômica e financeira -, nos levaram a crer que a Lei Anticorrupção encontra seu fundamento jurídico na tutela ao bem jurídico "moralidade pública", inscrito no art. 37, caput, da Constituição Federal. E por lá se atinar, diante da ausência de autorização constitucional expressa para proceder de modo distinto, encontra-se a responsabilidade por ela veiculada adstrita à regra geral de responsabilização sancionatória de agentes (com análise de culpa).

É claro que não se pretendeu no correr do presente estudo negar a existência de uma responsabilidade administrativa objetiva das pessoas jurídicas pela prática de atos de corrupção. Isso é patente, encontra-se plasmado nos art. $1^{\circ}$ e art. $2^{\circ}$ da Lei, e dizer o contrário significaria não apenas desprestigiar o legislador ordinário, mas reproduzir na temática vício antigo da doutrina, de assinalar como inconstitucional tudo aquilo que não é particularmente bem quisto. Todavia, o modo como a responsabilidade objetiva tem sido interpretada e implementada na matéria configura um mito que, se não desvendado a tempo, tende a tornarse verdade.

Criticar honestamente é buscar aprimorar os institutos previstos pela Lei Anticorrupção, por meio de sua contraposição ao direito posto e aos anseios sociais. Entendemos, destarte, que uma responsabilidade administrativa objetiva existe, mas não do modo que costumeiramente tem sido narrada.

Por se incluir no microssistema de tutela da moralidade pública, a responsabilidade administrativa anticorrupção deve, necessariamente, buscar meios de aferir a culpa das pessoas jurídicas - e isso, como tentou-se demonstrar, não leva ao falso contrassenso de uma responsabilidade objetiva subjetiva. A moralidade pública exige, ao lado de seu aspecto subjetivo (que se relaciona ao estado mental do agente, sua probidade), a observância a standards aceitáveis de conduta externalizada pessoal e corporativa, cuja inobservância permeia o próprio tipo sancionador conglobante.

No ano em que se comemora a efeméride de cinco anos de vigência da Lei Anticorrupção, é certo que ainda nos encontramos no período de sua maturação, mostrando- 
se oportuno, e quem sabe necessário, traçar delineamentos próprios, atinentes à realidade brasileira, para melhor compreensão e aplicação do instituto da responsabilidade administrativa objetiva por ela veiculado.

A responsabilização pressupõe uma relação obrigacional-imputacional. Para ser responsabilizado, há de se existir uma norma que estabeleça um dever jurídico originário atribuído à pessoa (natural ou jurídica), que uma vez violado dá ensejo à imputação de dever sucessivo, a responsabilidade. Para nós, na seara da responsabilidade administrativa anticorrupção, tais deveres correspondem ao "não-fazer" (dever negativo) estabelecido pela Lei Anticorrupção, mas também ao dever indeterminado de "fazer" (dever positivo) conforme arquétipo da moralidade objetiva constitucional. A pessoa jurídica, desse modo, ao não proporcionar meios que promovam tais deveres, fatalmente será responsabilizada.

Responsabilizar friamente sob o viés objetivo da tradição civilista, todavia, não nos parece ser juridicamente o mais acertado. A responsabilidade objetiva, em cuja preocupação estatal concentra-se na vítima lesada e sua reparação pelo dano acometido, possui claras e legítimas justificativas no âmbito do Direito Civil - notadamente em uma sociedade de risco, onde a gama de riscos abstratos e generalizados submete todos à potência constante de danos. Referida justificativa não é, apesar disso, apta a ser transplantada para a seara do Direito Administrativo Sancionador.

A Lei Anticorrupção, contrariamente ao salientado em sua tramitação legislativa, não visa precipuamente ressarcir prejuízos econômicos causados ao erário, ou estabelecer uma responsabilidade objetiva impura (responsabilidade por culpa de terceiro, heterorresponsabilidade ou vicarious liability). Tampouco se funda na teoria do risco, em qualquer de suas modalidades, sob pena de considerarmos como sendo da própria natureza da relação público-privada, o risco da atividade de, potencialmente, haver corrupção dessa mesma relação.

Afastando-se da finalidade ressarcitória (responsabilidade civil), a Lei Anticorrupção se afigura muito mais próxima dos contornos da responsabilidade penal, com suas finalidades preventiva e retributiva, pertencendo, entretanto, a um tertium genus, à responsabilidade administrativa, ou seja, ao sistema de responsabilização jurídico-estatal pela violação às normas de Direito Administrativo.

Em referido sistema, a sanção jurídica stricto sensu (sanção administrativa) caracteriza-se por possuir finalidade legitimadora híbrida, "preventivo-retributiva", buscando tanto retribuir o sujeito pelo ilícito cometido, quanto prevenir em suas múltiplas 
vertentes (geral negativa, geral positiva e especial positiva), o cometimento de ilícitos futuros, por meio da conformação atual de condutas.

Nesse passo, enquanto corte (i) retributivo, a sanção administrativa deve ser proporcional (i.a) à gravidade ético-social do ilícito, (i.b) à extensão do dano cometido, e (i.c) à culpabilidade própria do infrator; por sua vez, enquanto viés (ii) preventivo (notadamente especial positivo), deve a sanção administrativa ser equivalente à pena adequada e necessária à situação fática concreta, (ii.a) intimidando genericamente aqueles a quem a mera intimidação, ou estímulos gerais contrários, baste para não delinquir, (ii.b) promovendo a correção de comportamento daqueles mais tendentes ao cometimento do ilícito, e que por assim o ser, o cometem, ou (ii.c) neutralizando aqueles despidos de capacidade de correção.

De igual modo, tendo em vista o reconhecimento, no presente estudo, (i) de serem as pessoas jurídicas dotadas de condutas e valores próprios, dissociados das pessoas físicas dela integrantes, e aferíveis objetivamente pela sua externalização na sociedade que a circunda, posto que "instituições-organização", e (ii) de que o injusto direcionado à conduta de pessoas jurídicas necessita de aprimoramentos por meio da noção de um "injusto complexo" ou “global”, atrelado não apenas à conduta lesiva ao bem jurídico, mas também à sua culpa pela existência de um gap organizativo concretamente observável na estrutura interna dessa, parece-nos que a análise global do ilícito haverá de ser sempre considerada no juízo cognitivo realizado pelos agentes estatais no âmbito do processo de responsabilidade administrativa.

Veja-se que o processo sancionador administrativo deverá, tanto para melhor cotejar os fatos à sua finalidade retributiva-preventiva, quanto para efetuar o processo de subsunção do fato ao tipo conglobante, necessariamente iluminar e valorar não apenas o fato jurídico em si (a infração concretamente praticada), mas também seu agente (o infrator), originando uma sanção proporcional e equivalente à sua real necessidade, de acordo com sua culpabilidade.

É de destacar que pela sanção administrativa caracterizar-se por referida finalidade "preventivo-retributiva", à sua operacionalização é assegurada todo um rol de normas e princípios próprios, atrelados às garantias constitucionais mínimas outorgadas aos acusados em geral, o Direito Administrativo Sancionador. Enquanto ramo direcionado aos contornos do exercício da força sancionatória administrativo-estatal, o Direito Administrativo Sancionador tem como seu "primo-irmão" o Direito Penal, ambos atrelados às garantias 
processuais constitucionais e de limitação do exercício desmedido do ius puniendi. Todavia, a despeito de se aproximar da responsabilidade penal, e dos princípios e garantias nela incidentes, é impossível transpor-se de modo simplista as normas daquela à responsabilidade administrativa; há, claramente, a necessidade de cotejo, caso a caso, sob pena de se engessar de modo desmedido o processo administrativo. Por outro lado, não há como se admitir a imposição de processos kafkanianos aos administrados, sem a observância das garantias mínimas da legalidade, da tipicidade, da culpabilidade, do non bis in idem e do devido processo legal, todas essas previstas no art. $5^{\circ}$, da Constituição Federal.

As garantias dos acusados em geral - verdadeiro núcleo essencial que norteia qualquer processo punitivo, sejam eles processos penais ou administrativos - decorrem diretamente do texto constitucional e limitam toda a produção infranormativa, sendo vetores condicionantes da responsabilidade.

É certo, não obstante, que tal regime de Direito Administrativo Sancionador não se manifestará de modo uniforme em todos os seus braços, cabendo uma aplicação heterodoxa, a partir de sua incidência dinâmica com maior, ou menor, intensidade, a depender do contexto específico da norma secundária abstrata. Quanto mais próxima da retributividade for a finalidade sancionatória, mais presente se fará necessária a estrita observância ao regime de Direito Administrativo Sancionador - no caso, ao analisar-se as sanções previstas na Lei Anticorrupção, entendemos claramente aplicável as garantias oriundas de referido regime.

Ao fugir das fórmulas tradicionalmente adotadas para sancionar a prática de atos de corrupção, a Lei Anticorrupção buscou afastar-se dos questionamentos acerca da culpabilidade corporativa. Ocorre que, para tanto, importou da legislação internacional soluções compatíveis com a história e os valores próprios daquelas sociedades, descurando do sistema normativo brasileiro, no qual a garantia constitucional de aferição da culpa há de ser prestigiada em seu sentido de "culpa própria". Eis a grande problemática da Lei Anticorrupção.

Buscamos demonstrar ao longo do estudo que, a despeito de parcela significativa da doutrina ora aproximar a responsabilidade veiculada pela Lei Anticorrupção às teorias do risco civil, ora à heterorresponsabilização com aferição de culpa da pessoa física, a interpretação da Lei melhor se acomodaria aos dispositivos da Constituição Federal e aos princípios e garantias vetores do processo administrativo sancionador, mediante a autorrresponsabilização das pessoas jurídicas. 
A partir de tal construção doutrinária seria possível assegurar uma responsabilização “objetivável”, por meio da aferição da compatibilidade de condutas externalizadas pela pessoa jurídica com as expectativas dela esperadas pelo Direito, permitindo-se a concessão de juízos de exculpação - o que, inclusive, iria ao encontro da nova tendência internacional.

A própria redação do art. $3^{\circ}$ da Lei Federal $n^{\circ}$ 9.605/1998, que estabeleceu a responsabilidade penal das pessoas jurídicas pela prática de ilícitos ambientais, e em muito se assemelha ao do art. $2^{\circ}$ da Lei Anticorrupção, sofreu alterações em sua interpretação ao longo do tempo, o que ilustraria a possibilidade da trajetória proposta no presente trabalho. Como salientado oportunamente, a despeito de, em um primeiro momento, doutrina e jurisprudência terem reconhecido em tal dispositivo legal a existência de heterorresponsabilidade (tal qual faz parcela da doutrina administrativa acerca da Lei Anticorrupção), com a evolução da matéria, caminha-se, cada vez mais, para se aproximar a aferição da culpa de terceiros à existência de vícios internos na estrutura da pessoa jurídica, que justificariam seu sancionamento pela inobservância ao dever legal de prevenção.

É possível portanto (e arrisca-se, até mesmo salutar) que a interpretação normativa caminhe em um sentido diverso do texto frio, priorizando a melhor acomodação da responsabilidade objetiva veiculada pela Lei Anticorrupção ao ordenamento jurídico. Ainda mais quando considerado que, mesmo nas franjas do Direito Administrativo onde se costumava aceitar a existência de uma suposta responsabilidade objetiva (nos processos administrativos tributários e ambientais), a evolução doutrinária e jurisprudencial igualmente sepultou quaisquer dúvidas quanto à sua impossibilidade, sedimentando, em verdade, a existência de uma responsabilidade subjetiva por culpa presumida - que não afasta do processo sancionatório a necessária análise da culpa.

Ao defrontarmo-nos com o disposto nos art. $6^{\circ}, \S 1^{\circ}$ e art. $7^{\circ}$, da Lei Anticorrupção, vislumbramos a base legal para a construção da responsabilidade administrativa nos moldes propostos. Isso porque, nos termos de referidos dispositivos, o agente sancionador haverá de considerar, durante o juízo cognitivo do processo sancionador, as condições e circunstâncias do ilícito, não se atendo apenas à infração em si, mas igualmente à própria pessoa jurídica inclusive como reflexo das expectativas sociais esperadas sobre tal ou qual pessoa jurídica, ou sobre a atividade que exerce (que poderá necessitar maiores, ou menores esforços preventivos por parte da pessoa jurídica).

É sobre tais elementos que cogitamos a possibilidade de aferição da culpabilidade corporativa própria no processo de autorresponsabilidade das pessoas jurídicas, no qual os 
programas e mecanismos de integridade poderão vir a desempenhar relevante papel tanto (i) na identificação dos valores corporativos próprios, quanto (ii) na exposição da cultura empresarial engajada (ou não) com a legalidade e a integridade que, por sua vez, conformará o defeito de organização característico para fim de sancionamento. Adicionalmente, a sugestão de mudança de postura entre as partes da relação jurídico-sancionatória, mais responsiva e cooperativa, poderá favorecer um ambiente público-privado mais íntegro - e, portanto, mais aderente ao bem-jurídico "moralidade pública -, sem desbordar das competências atualmente já outorgadas à CGU.

Mostra-se claro assim, para nós, que a resposta acerca da conveniência legal, ou não, da utilização da responsabilidade aferida de modo objetivo, dependerá sempre da finalidade que a legislação buscar atingir. Enquanto efetividade na reparação integral dos direitos patrimoniais afetados, não há dúvidas de que a responsabilidade objetiva atenda a tal pleito. Contudo, extravasar a responsabilidade objetiva da esfera da responsabilidade civil para os ramos do Direito Sancionador pode não ser uma tarefa fácil, dada as incompatibilidades existentes entre os próprios sistemas.

Enquanto a responsabilidade civil possui seu referencial nas vítimas e na recuperação da lesão patrimonial, o Direito Penal e o Direito Administrativo são, por excelência, o exercício do ius puniendi pelo Estado, que, valendo-se da legitimidade do uso da força, não pode atingir o sujeito sem a observância de quaisquer garantias. A responsabilidade subjetiva antes de ser uma famigerada forma de imiscuir-se da responsabilidade patrimonial, é uma garantia do sujeito em controlar o monopólio da violência estatal. Enquanto garantia, a responsabilidade subjetiva traz consigo todo o rol das garantias fundamentais que impedem a transmissão da pena e impõe o dever de razoabilidade e proporcionalidade na aplicação das sanções, de acordo com um devido processo legal. Tais elementos, como visto, muitas vezes não conseguem ser observados na responsabilidade objetiva, pois, para atingir seus objetivos, é pressuposto imanente que a responsabilidade possa transmitir a obrigação de reparar para terceiros (ao empregador, ao comitente, à pessoa jurídica) e em quantum equivalente e proporcional ao dano, sem depender tal proporcionalidade de qualquer caráter repressivo-preventivo ao sujeito.

Entendemos, destarte, que a adoção pela Lei Anticorrupção do modelo de responsabilidade objetiva como resposta jurídica ao cometimento do ilícito deveu-se primeiramente a uma postura pragmática do legislador infraconstitucional, e, posteriormente, à importação de modelos estrangeiros "pré-fabricados" (baseados em 
vicarious liability) que não se coadunaram, após a promulgação da Lei, ao ordenamento jurídico pátrio e, tampouco, à própria finalidade sancionatória dela.

Fórmulas prontas e alienígenas, tal qual os termos da responsabilidade objetiva apresentada pela Lei, somente conseguem dar parte da resposta estatal necessária ao complexo fenômeno da ilicitude decorrente dos atos de corrupção. Se de um lado, a responsabilização objetiva garante a eficácia na recomposição do erário, tornando "garantes" as pessoas jurídicas meramente por terem maiores disponibilidades econômicas, por outro lado não atende ao dever de correção do comportamento corruptivo para sobrevivência das instituições, da democracia ou do próprio Estado.

Conforme exposto ao longo da presente pesquisa, o combate à corrupção é um dever ético e legal do Estado para com a população, na medida em que os custos inerentes à manutenção de sistemas corruptivos afetam consideravelmente o desenvolvimento das nações. Além disso, um dos maiores perigos da manutenção de sistemas corruptivos está na própria quebra de confiança depositada pelos administrados nas instituições postas, levando à instabilidade das relações sociais e à descrença no poder estatal em garantir os direitos fundamentais. A confiança nas instituições, enquanto decorrente do princípio da boa-fé e da segurança jurídica, é diretamente proporcional ao nível de moralidade aferível nas relações público-privadas.

Trata-se de uma política de Estado constantemente em evolução que, a despeito de sua importância, não se encontra ainda muito bem delineada no Brasil. A Lei Anticorrupção, conquanto se mostre, por um lado, consentânea aos anseios populares de eficientismo punitivo, ainda necessita de um amadurecimento aplicativo e interpretativo por parte de todos os seus atores - Administração Pública, agentes sancionadores e pessoas jurídicas visando uma postura mais cooperativa, proativa e educativa de parte a parte.

O presente trabalho busca retomar as premissas da importância de uma base moral do Estado, suscita o debate entre Direito e Moral nos contornos da moralidade pública trazida pela Constituição Federal de 1988, e visa estabelecer possíveis enunciações para a determinação legal de uma atuação íntegra por ambas as partes das relações público-privadas e, portanto, respeitadora da lei, da moral e da ética. Porta-se, assim, como um gérmen à espera de poder gerar frutos futuros na discussão da temática - tão necessária em nossos dias atuais.

A corrupção, enquanto utilização desviada de competências próprias, legais ou obrigacionais, exercidas de modo a deteriorar, corromper, ou violar as regras de conduta da 
relação público-privada em benefício do agente ou de terceiros, corresponde a verdadeiro desprezo pelas expectativas morais depositadas pela sociedade no exercente de tais competências. É quebra da "palavra dada" ao aceitar um múnus público (no caso dos agentes públicos), mas igualmente daquela dada pelo particular ao lançar mão de sua liberdade para o exercício de uma atividade.

Há de se relembrar o mantra: não existe exercício de liberdade sem o ônus de sua responsabilidade. As pessoas jurídicas enquanto "instituições-organização" não estão, após a Lei Anticorrupção, moral e legalmente autorizadas a se desvincularem do dever de se comportar, bem como de promover comportamentos, de modo prossocial, cooperativo e, principalmente, responsável.

A legislação brasileira se sustenta não apenas a partir dos valores morais da sociedade cristalizados na Constituição Federal, mas também de suas expectativas morais de atuação do Estado de modo confiável, razoável e proporcional, como substituto do agente privado no processo de responsabilização do infrator.

Não se mostra viável, à luz de nosso ordenamento, autorizar o arbítrio do "grande médico Dr. Simão Bacamarte", a internar em sua "Casa Verde" qualquer sujeito sem analisar concretamente suas condições fáticas. As instituições estatais perenes, atualmente desacreditadas, não podem alinhar o exercício de suas atividades aos pleitos da "opinião pública", sem qualquer controle ou discernimento crítico, tomando como parâmetro da proporcionalidade o desejo "punitivista" ou a existência de "cruzadas ideológicas". Tal postura deslegitima o próprio monopólio da força pelo Estado, e deve ser fortemente evitado.

As sanções preventivo-retributiva estatais, por força do art. $5^{\circ}$ da Constituição Federal, hão de ser aplicadas de modo subjetivo, assegurando-se a quaisquer acusados em geral (sejam eles pessoas naturais ou jurídicas) a efetiva perquirição de sua culpabilidade. Essa, se quando das pessoas naturais se constata pelo animus delinquendi, quando transposta às pessoas jurídicas, é possível de ser aferível por uma "meta-vontade" própria, resultado do somatório de características reguladas pelo Direito, e relacionadas aos valores por elas externalizadas perante a sociedade.

Os delineamentos ora traçados visam conscientizar, no necessário processo de amadurecimento e evolução da compreensão da Lei, que a responsabilidade das pessoas jurídicas é contraparte da liberdade, notadamente na medida em que " $[\mathrm{t}] \mathrm{u}$ deviens responsable pour toujours de ce que tu as apprivoisé"; condensando-se, nessas pequenas 
palavras da majestosa obra de ANTOINE DE SAINT-EXUPÉRY, toda a essência da responsabilidade. 


\section{REFERÊNCIAS BIBLIOGRÁFICAS}

ABELHA, Carlos Fernando Lopes Abelha. Os efeitos danosos do crime organizado e da corrupção dos agentes públicos e privados no desenvolvimento econômico no País. Mestrado em Direito. Pontifícia Universidade Católica de São Paulo (PUC/SP). 2011.

ADRI, Renata Porto. Et alli. Corrupção, ética e moralidade administrativa. Belo Horizonte: Fórum, 2008.

AFONSO DA SILVA, José. Curso de Direito Constitucional Positivo. São Paulo: Malheiros Editores, 2012.

AGUIAR, Adriana. Espírito Santo é o primeiro a aplicar Lei Anticorrupção. Jornal Valor Econômico. Publicado em 15 de janeiro de 2016.

ALBUQUERQUE, Ana Claudia de Paula. A responsabilidade objetiva administrativa da empresa na Lei no 12.846/2013. Revista Brasileira de Estudos da Função Pública-RBFEP. N. 9. Belo Horizonte, 2014. P. 235, 247.

ALMEIDA, Fernanda Dias Menezes de. Competências na Constituição de 1988. $6^{\text {a Ed. São }}$ Paulo: Atlas, 2013.

ALMEIDA, Gabriel Bertin de. A crise do conceito tradicional de culpabilidade, segundo o direito penal contemporâneo. Revista Brasileira de Ciências Criminais - RBCC. Vol. 35/2001. São Paulo: Revista dos Tribunais. Versão obtida digitalmente. P. 37, 54.

ALMEIDA, Maria da Glória Villaça Borin Gavião de; WADA, Ricardo Morishita. Os sistemas de responsabilidade no código de defesa do consumidor. Aspectos gerais. Doutrinas Essenciais de Responsabilidade Civil. Vol. 4. São Paulo: Revista dos Tribunais, 2011. Versão obtida digitalmente. P. 309, 330.

ALVAREZ, Inma Valeije. Elementos estructurales para una tipificación de la corrupción en la Unión Europea. In BAIGUN, David; RIVAS, Nicolás García (dir). Delincuencia económica y corrupción. $1^{\mathrm{a}}$ Ed. Buenos Aires: Ediar, 2006. P. 159, 220.

ALVES, Rogério Pacheco; GARCIA, Emerson. Improbidade administrativa. $8^{\mathrm{a}}$ Ed. São Paulo: Saraiva, 2014.

ALVES, Roque de Brito. A responsabilidade penal da pessoa jurídica. Doutrinas Essenciais de Direito Penal Econômico e da Empresa. Vol. 1. São Paulo: Revista dos Tribunais, 2011. Versão obtida digitalmente. P. 1199, 1206. 
ALVIM, Agostinho. Da inexecução das obrigações e suas consequências. $5^{\text {a }}$ Ed. São Paulo: Saraiva, 1980.

ARANHA FILHO, Adalberto José Queiroz Telles de Camargo. Direito penal: crimes contra a Administração Pública. São Paulo: Atlas, 2006.

ARAÚJO, Edmir Netto de. Curso de Direito Administrativo. São Paulo: Saraiva, 2009.

ARÊDE, Sirlene. Responsabilização do Agente Público - Individualização da sanção por ato de Improbidade administrativa. Belo Horizonte: Fórum, 2012.

ARIAS, Jacinto Pérez. Sistema de atribución de responsabilidad penal a las personas jurídicas. 2013. Tese (Doutorado em Direito Penal) - Universidad de Murcia, Murcia.

ARISTÓTELES. Ética a Nicômaco. Trad. Leonel Vallandro e Gerd Bornheim. Nova Cultural, 1991.

ARISTÓTELES. Sobre a geração e a corrupção. Trad. Francisco Chorão. Centro de Filosofia da Universidade de Lisboa. Lisboa: Imprensa Nacional - Casa da Moeda, 2009.

ASSIS TOLEDO, Francisco de. Princípios básicos de direito penal. $4^{\mathrm{a}}$ Ed. São Paulo: Saraiva, 1991.

ATALIBA, Geraldo. Imposto de renda - Multa punitiva. Revista de Direito Administrativo, Rio de Janeiro, v. 126, p. 547-557, dez. 1976. ISSN 2238-5177. Disponível em: http://bibliotecadigital.fgv.br/ojs/index.php/rda/article/view/42096. Acesso em: 31.05. 2018.

ÁVILA, Humberto. Constituição, liberdade e interpretação. São Paulo: Malheiros, 2019.

AZEVEDO, Álvaro Vilaça. Teoria geral das obrigações e responsabilidade civil. $12^{\mathrm{a}}$ Ed. São Paulo: Atlas, 2011.

AZEVEDO, Álvaro Villaça. Proposta de classificação da responsabilidade objetiva: pura e impura. Revista de Direito Privado. Vol. 83. Ano. 18. P. 229,236. São Paulo: RT, 2017.

AZEVEDO, André Mauro Lacerda. Bribery act 2010: um novo paradigma no enfrentamento da corrupção. Revista Brasileira de Ciências Criminais. V. 113/2015. São Paulo, 2015. P. 411, 439. 
AZEVEDO, Vicente de Paulo Vicente de. O fundamento da responsabilidade civil extracontratual. Doutrinas Essenciais de Responsabilidade Civil. Vol. 1. São Paulo: Revista dos Tribunais, 2011. Versão obtida digitalmente. P. 373, 390.

BANDEIRA DE MELLO, Celso Antônio. Curso de Direito Administrativo. $30^{\text {a }}$ Ed. São Paulo: Malheiros, 2013.

BANDEIRA DE MELLO, Oswaldo Aranha. Princípios gerais de direito administrativo. V. I, Rio de Janeiro: Forense, 1969.

BANDEIRA DE MELLO, Oswaldo Aranha. Princípios gerais de direito administrativo. V. II. Rio de Janeiro: Forense, 1974.

BANDEIRA, Luiz Octávio de Viana. Notas sobre a natureza e o alcance da responsabilidade objetiva das pessoas jurídicas por atos contra a administração pública na Lei Anticorrupção. In CASCIONE, Fábio de Souza Aranha; RIBEIRO, Bruno Salles Pereira. Lei anticorrupção: uma análise interdisciplinar. São Paulo: LiberArs, 2015. P. 29, 44.

BARBOSA, Julianna Nunes Targino. A culpabilidade da responsabilidade penal da pessoa jurídica. 2014. Dissertação (Mestrado em Direito Penal) - Faculdade de Direito, Universidade de São Paulo, São Paulo.

BARREIRA, Érika Campos; BORGES, Monike Valent Silva. Princípio da prevenção e a ética da responsabilidade de Hans Jonas na mineração brasileira. In REIS, Émilien Villa Boas (org). Entre a filosofia e o ambiente: bases filosóficas para o Direito Ambiental. Belo Horizonte: 3i Editora, 2014. P. 93, 115.

BARROS, Zanon de Paula. Questões atinentes à chamada lei anticorrupção. Revista de Direito Empresarial. V. 2/2014. São Paulo: RT, 2014. Versão obtida digitalmente. P. 257.

BARROSO, Luís Roberto. Neoconstitucionalismo e constitucionalização do Direito. Doutrinas essenciais de Direito Constitucional. V. 7. São Paulo: RT, 2015. P. 533, 584.

BASTOS, Celso Ribeiro. Comentários ao artigo 173, §5. In BASTOS, Celso Ribeiro. MARTINS, Ives Gandra. Comentários à Constituição do Brasil. V. 7. São Paulo: Saraiva, 1990. P. 103, 105.

BASTOS, Fabrício Rocha. Do microssistema da tutela coletiva e a sua interação com o CPC/2015. Revista do Ministério Público do Rio de Janeiro. Nº 68. Abr/jun. 2018. P. 57, 132. 
BASTOS, Rosaura Moreira Brito. Improbidade Administrativa - Conteúdo Jurídico e Dimensão Constitucional. Belo Horizonte: Fórum, 2010.

BATISTA, Adriano Jamal. Responsabilidade civil: critérios restritivos na interpretação da atividade de risco. 2008. Dissertação (Mestrado) - Faculdade de Direito, Universidade de São Paulo, São Paulo.

BECKER, Gary S.; STIGLER, George J. Law enforcement, malfeasance, and the compensation of enforcers. Journal of legal studies 3, n. 1. Jan. 1974. P. 1, 18. Disponível em https://www.journals.uchicago.edu/doi/10.1086/467507. Acesso em 20.11.2018.

BENJAMIN, Antonio Herman de Vasconcelos e. Responsabilidade civil pelo dano ambiental. Doutrinas Essenciais de Responsabilidade Civil. Vol. 7. São Paulo: Revista dos Tribunais, 2011. Versão obtida digitalmente. P. 453, 515.

BERTOCCELLI, Rodrigo de Pinho. Compliance. In CARVALHO, André Castro, et alli (Coord.). Manual de compliance. Rio de Janeiro: Forense, 2019. P. 37, 54.

BERTOCINI, Mateus (org). Lei Anticorrupção. Comentários à lei 12.846/2013. Lisboa: Almedina Brasil, 2014.

BIDINO, Claudio. Responsabilidade penal da pessoa jurídica no Brasil e teoria da dupla imputação necessária: comentários ao Acórdão RE 548.181 do STF. Revista Brasileira de Ciências Criminais. Vol. 123/2016. São Paulo: Revista dos Tribunais, 2016. Versão obtida digitalmente. P. 383, 405.

BIM, Eduardo Fortunato. O mito da responsabilidade objetiva no direito ambiental. Doutrinas essenciais de direito ambiental. V. 5. São Paulo: RT, 2011. P. 807, 839.

BISSOLI, Leonardo. Controle da corrupção e discricionariedade: os meios da accountability dos agentes públicos e as licitações e contratações públicas. 2018. Dissertação (Mestrado em Direito) - Faculdade de Direito, Universidade de São Paulo, São Paulo.

BITTENCOURT, Darlan Rodrigues. Lineamentos da responsabilidade civil ambiental. Doutrinas Essenciais de Responsabilidade Civil. Vol. 7. São Paulo: Revista dos Tribunais, 2011. Versão obtida digitalmente. P. 243, 300.

BITTENCOURT, Sidney. Comentários à lei anticorrupção. $2^{\mathrm{a}}$ Ed. São Paulo: Editora Revista dos Tribunais, 2015. 
BLOK, Marcella. A nova lei anticorrupção e o compliance. Revista de Direito Bancário e do Mercado de Capitais. V. 65/2014. São Paulo: RT, 2014. Versão obtida digitalmente. P. $263,318$.

BOBBIO, Norberto. Teoria da norma jurídica. São Paulo: Edipro, 2001.

BONCHRISTIANO, Ana Cristina Ribeiro. A culpabilidade jurídico-penal. Doutrinas Essenciais de Direito Penal. Vol. 3. São Paulo: Revista dos Tribunais, 2010. Versão obtida digitalmente. P. 25, 36.

BONFIM. Natália Bertolo. A desconsideração da personalidade jurídica na lei anticorrupção. Revista dos Tribunais. V. 947/2014. São Paulo: Editora Revista dos Tribunais. Versão obtida digitalmente. P. 91.

BOTELHO, Ana Cristina Melo de Pontes. Corrupção política: uma patologia social. Belo Horizonte: Fórum, 2010.

BRANCO, Daniela Holler. Responsabilidade penal das corporações: lições dos sistemas jurídicos anlgo-saxões. Doutrinas Essenciais de Direito Penal Econômico e da Empresa. Vol. 1. São Paulo: Revista dos Tribunais, 2011. Versão obtida digitalmente. P. 847, 875.

BRANDÃO, Antônio José. Moralidade administrativa. Revista de Direito Administrativo, V. 25. Rio de Janeiro, 1951. P. 454, 467.

BRASIL. Controladoria Geral da União. Guia de implantação de programas de integridade nas empresas estatais. Brasília, 2015. Disponível em https://cgu.gov.br/Publicacoes/etica-eintegridade/arquivos/guia_estatais_final.pdf. Acesso em 15.06.2019.

BRASIL. Controladoria Geral da União. Guia prático das unidades de gestão de integridade. Brasília, 2019. Disponível em https://cgu.gov.br/Publicacoes/etica-eintegridade/arquivos/unidades-de-gestao.pdf. Acesso em 15.06.2019.

BRASIL. Controladoria Geral da União. Programas de integridade. Diretrizes para empresas privadas. Brasília, 2015. Disponível em https://cgu.gov.br/Publicacoes/etica-eintegridade/arquivos/programa-de-integridade-diretrizes-para-empresas-privadas.pdf.

Acesso em 15.06.2019.

BRASIL. Controladoria-Geral da União. Convenção da OCDE. Brasília: CGU, 2007.

BRASIL. Governo do Brasil. Atos internacionais. Disponível em http://www.brasil.gov.br/governo/2012/05/atos-internacionais. Acesso em 05.12.2018. 
BRASIL. Mensagem EM $n^{o}$ 005/2006/CGU-PR. Disponível em http://www.camara.gov.br/proposicoesWeb/prop mostrarintegra:jsessionid=0D0ABE5EC 94F3E1368E8CF476BA44657.proposicoesWebExterno2? codteor=422282\&filename=Tra mitacao-PL+7528/2006. Acesso em 19.12.2018.

BRASIL. Mensagem EMI no 000112009 - CGU/MJ/AGU, de 23 de outubro de 2009. Disponível em http://www.camara.gov.br/proposicoesWeb/prop_mostrarintegra?codteor=735505\&filena $\underline{m e=T r a m i t a c a o-P L+6826 / 2010}$. Acesso em 19.12.2018.

BRASIL. Ministério da Transparência e Controladoria Geral da União. Manual para implementação de programas de integridade. Brasília, 2017. Disponível em https://cgu.gov.br/Publicacoes/etica-e-integridade/arquivos/manual profip.pdf. Acesso em 15.06.2019.

BRASIL. Ministério da Transparência e Controladoria Geral da União. Guia prático de gestão de riscos para a integridade. Brasília, 2018. Disponível em https://cgu.gov.br/Publicacoes/etica-e-integridade/arquivos/manual-gestao-de-riscos.pdf.

Acesso em 15.06.2019.

BRASIL. Ministério da Transparência. Convenções internacionais. Disponível em http://www.cgu.gov.br/assuntos/articulacao-internacional/convencoes-internacionais.

Acesso em 03.12.2018.

BRASIL. Parecer do Relator Deputado Carlos Zarattini, apresentado em Comissão Especial, datado de 19.04.2012. Disponível em http://www.camara.gov.br/proposicoesWeb/prop_mostrarintegra? codteor=982072\&filena $\underline{m e}=$ Tramitacao-PL+6826/2010. Acesso em 19.12.2018.

BRASIL. Parecer do Senado $\mathrm{n}^{\circ}$ 649, de 2013, apresentado em Plenário, datado de 04.07.2013. Disponível em https://legis.senado.leg.br/sdleggetter/documento?dm=4003724\&ts $=1543021110297 \&$ disposition=inline. Acesso em 19.12.2018.

BRASIL. Presidência da República. Subchefia de Análise e Acompanhamento de Políticas Governamentais. Diretrizes gerais e guia orientativo para elaboração de Análise de Impacto Regulatório. $\quad$ Brasília: $2018 . \quad$ Disponível em http://www.casacivil.gov.br/governanca/regulacao/apresentacao-regulacao-pasta/acesseaqui/comite-interministerial-de-governanca-aprova-as-diretrizes-gerais-e-roteiro-analiticosugerido-para-analise-de-impacto-regulatorio-diretrizes-air-e-o-guia-orientativo-paraelaboracao-de-analise-de-impacto-regulatorio-guiaair/diretrizes_guia_air_cig_11junho2018.pdf/view. Acesso em 07.07.2019. 
BRASIL. PRL 1 PL682610, apresentado em Comissão Especial, datado de 14.03.2012. Disponível em http://www.camara.gov.br/proposicoesWeb/prop_mostrarintegra?codteor=970659\&filena

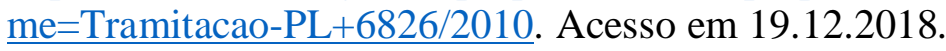

BRASIL. Tribunal de Contas da União. Referencial de combate a fraude e corrupção: aplicável a órgãos e entidades da administração pública. $2^{a}$ Ed. Brasília, 2018. Disponível em https://portal.tcu.gov.br/biblioteca-digital/referencial-de-combate-a-fraude-ecorrupcao.htm. Acesso em 15.06.2019.

BRUNO, Aníbal. Direito penal: parte geral. $2^{\text {a }}$ Ed. V. 1. Tomo 2. Rio de Janeiro: Forense, 1959.

BRUNONI, Nivaldo. Princípio da culpabilidade: considerações. Curitiba: Juruá, 2008.

BULOS, Uadi Lammêgo. Constituição Federal anotada. $7^{a}$ Ed. São Paulo: Saraiva, 2007.

BULOS, Uadi Lammego. Curso de Direito Constitucional. São Paulo: Saraiva, 2015.

CABETTE, Eduardo Luiz Santos. Responsabilidade penal da pessoa jurídica. Breve estudo crítico. Doutrinas Essenciais de Direito Penal. Vol. 3. São Paulo: Revista dos Tribunais, 2010. Versão obtida digitalmente. P. 259, 290.

CAHALI, Yussef Said. Responsabilidade civil do Estado. $4^{\text {a }}$ Ed. São Paulo: RT, 2012.

CAMARGO, Antonio Luis Chaves. Motivo, vontade, intenção, dolo. 1986. Tese (Livredocência em Direito Penal). Faculdade de Direito - Universidade de São Paulo, São Paulo.

CAMMAROSANNO, Márcio. Princípio constitucional da moralidade e o exercício da função administrativa. Belo Horizonte: Fórum, 2006.

CAMPOS, Patrícia Toledo de. Comentários à Lei no 12.846/2013 - Lei anticorrupção. Revista Digital de Direito Administrativo. Ribeirão Preto: Faculdade de Direito de Ribeirão Preto, 2014. Versão obtida digitalmente.

CAMPOS, Tomás Cano. Non bis in idem, prevalencia de la via penal y teoria de los concursos en el derecho administrativo sancionador. Revista de Administración Pública. N. 156. Madrid, 2001. P. 191, 249.

CANOtIlHO, J. J. Gomes; MENDES, Gilmar Ferreira. Comentários à Constituição do Brasil. São Paulo: Saraiva, 2013. 
CAPEZ, Fernando. Improbidade administrativa: limites constitucionais. $2^{\mathrm{a}}$ Ed. São Paulo: Saraiva, 2015.

CAPPELLI, Silvia. Responsabilidade penal da pessoa jurídica em matéria ambiental: uma necessária reflexão sobre o disposto no art. $225, \S 3^{\circ}$ da Constituição Federal. Doutrinas Essenciais de Responsabilidade Civil. Vol. 7. São Paulo: Revista dos Tribunais, 2011. Versão obtida digitalmente. P. 349, 358.

CARDOSO, Raphael de Matos. A responsabilidade da pessoa jurídica por atos de improbidade e corrupção. Rio de Janeiro: Lumen Juris, 2019.

CARLOS DE OLIVEIRA, Ana Carolina. Direito de intervenção e direito administrativo sancionador: o pensamento de Hassemer e o Direito Penal Brasileiro. 2012. Dissertação (Mestrado em Direito Penal) - Faculdade de Direito, Universidade de São Paulo, São Paulo.

CARRACEDO, José Rubio. La fuente de la corrupción política: la teoría de Rousseu sobre las tres voluntades del ciudadano. Revista de Estudios Políticos (nиeva época). N. 141. Madrid: 2008. P. 105, 132.

CARVALHO, Érika Mendes de; CARVALHO, Gisele Mendes de. Direito penal de risco e responsabilidade penal das pessoas jurídicas: a propósito da orientação jurisprudencial do STJ. Doutrinas Essenciais de Direito Penal Econômico e da Empresa. Vol. 1. São Paulo: Revista dos Tribunais, 2011. Versão obtida digitalmente. P. 939, 962.

CARVALHO, Paulo de Barros. Direito tributário - linguagem e método. $5^{\text {a }}$ Ed. São Paulo: Noeses, 2013.

CARVALHO, Paulo Roberto Galvão de. Legislação anticorrupção no mundo: análise comparativa entre a Lei Anticorrupção Brasileira, o Foreign Corrupt Practices Act NorteAmericano e o Bribery Act do Reino Unido. In SOUZA, Jorge Munhós de; QUEIROZ, Ronaldo Pinheiro de. Lei Anticorrupção. Salvador: JusPODIVM, 2015. P. 35, 62.

CARVALHOA, Modesto. A medida provisória do escárnio. Jornal O Estado de São Paulo. Publicado em 29.12.2015.

CARVAlHOSA, Modesto (coord.). O Livro Negro da Corrupção. São Paulo: Paz e Terra, 1995.

CARVALHOSA, Modesto. Considerações sobre a lei anticorrupção das pessoas jurídicas. São Paulo: Revista dos Tribunais, 2015. 
CASADO, Márcio Mello. Responsabilidade objetiva no código de defesa do consumidor justificativas, precedentes e análise do sistema nacional. Doutrinas Essenciais de Responsabilidade Civil. Vol. 4. São Paulo: Revista dos Tribunais, 2011. Versão obtida digitalmente. P. 587, 624.

CASCIONE, Fábio de Souza Aranha. RIBEIRO, Bruno Salles Pereira. Lei Anticorrupção: uma análise interdisciplinar. São Paulo: Editora Liberas, 2015.

CASERMEIRO, Pablo Rando. La distinción entre el Derecho penal y el Derecho administrativo sancionador. Valencia: Tirant lo Blanch, 2010.

CASTRO, Fabiana Maria Martins Gomes de. Sociedade de risco e o futuro do consumidor. Doutrinas Essenciais de Responsabilidade Civil. Vol. 4. São Paulo: Revista dos Tribunais, 2011. Versão obtida digitalmente. P. 625, 647.

CAVALIERI FILHO, Sergio. Programa de responsabilidade civil. 10ª Ed. São Paulo: Atlas, 2012.

CAVALIERI FILHO, Sergio. Responsabilidade civil no Novo Código Civil. Revista de Direito do Consumidor. Vol. 48/2003. São Paulo: RT, 2003.

COELHO, Sacha Calmon. A transferibilidade da responsabilidade por multas fiscais. Revista de Crítica Judiciária, v. 3, 1987;

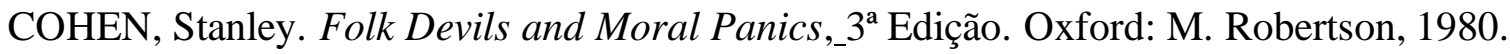

COIMBRA, Marcelo de Aguiar; MANZI, Vanessa Alessi (org). Manual de compliance. São Paulo: Atlas, 2010.

CONFÚCIO. Os Analectos. Trad. do inglês Caroline Chang. Trad. do Chinês por D. C. Lau. L\&PM Pocket. [n/d]

COPOLA, Gina. A Improbidade Administrativa no Direito Brasileiro. Belo Horizonte: Fórum, 2011.

CORDOVIL, Leonor. Comentário ao Capítulo II - Das infrações. In CORDOVIL, Leonor, et alli. Nova lei de defesa da concorrência comentada. Lei 12.529, de 30 de novembro de 2011. P. 100, 117.

CORRÊA DE OLIVEIRA, J. Lamartine. A dupla crise da pessoa jurídica. São Paulo: Saraiva, 1979. 
CORRÊA DE OLIVEIRA, J. Lamartine. Conceito de pessoa jurídica. 1962. Tese (Livredocência em Direito) - Faculdade de Direito - Universidade Federal do Paraná, Curitiba.

CORRÊA, Tatiana Machado. Em busca de um conceito latino-americano de culpabilidade. Doutrinas Essenciais de Direito Penal. Vol. 3. São Paulo: Revista dos Tribunais, 2010. Versão obtida digitalmente. P. 957, 980.

CORRÊA, Tatiana. Crítica ao conceito funcional de culpabilidade de Jakobs. Doutrinas Essenciais de Direito Penal. Vol. 3. São Paulo: Revista dos Tribunais, 2010. Versão obtida digitalmente. P. 981, 1004.

COSTA JUNIOR, Paulo José da. Comentários ao código penal. V. 3. São Paulo: Saraiva, 1989.

COSTA, Helena Regina Lobo da. Corrupção na História do Brasil: reflexões sobre suas origens no período colonial. In DEL DEBBIO, Alessandra; MAEDA, Bruno Carneiro; AYRES, Carlos Henrique da Silva. Temas de anticorrupção \& compliance. São Paulo: Campus Jurídico, 2013. P. 1, 20.

COSTA, Helena Regina Lobo da. Direito administrativo sancionador e direito penal: a necessidade de desenvolvimento de uma política sancionadora integrada. In BLAZECK, Luiz Mauricio Souza, MARZAGÃO JÚNIOR, Laerte I. (coords) Direito Administrativo Sancionador. São Paulo: Quartier Latin, 2014. P, 108, 118.

COSTA, Helena Regina Lobo da. Direito penal econômico e direito administrativo sancionador. 2013. Tese (Livre-docência em Direito) - Faculdade de Direito, Universidade de São Paulo, São Paulo.

COSTA, Helena Regina lobo da. Proteção ambiental, direito penal e direito administrativo. 2007. Tese (Doutorado em Direito Penal) - Faculdade de Direito, Universidade de São Paulo, São Paulo.

COSTA, Helena Regina Lobo. Proteção ambiental, direito penal e direito administrativo. Tese (Doutorado em Direito Penal). 2007. Faculdade de Direito - Universidade de São Paulo, São Paulo. P. 181, 182.

COSTA, Susana Henriques da. O processo coletivo na tutela do patrimônio público e da moralidade administrativa. São Paulo: Quartier Latin, 2009.

COUTINHO, Nilton C. A. Probidade e ética na gestão pública: a Lei $\mathrm{n}^{\circ}$ 12.846/2013 e importância do advogado público no combate à corrupção. Revista Fórum Administrativo FA. N. 171. Belo Horizonte, 2015. P. 65, 70. 
CUÉLLAR. Leilla. PINHO, Clóvis Alberto Bertolini de. Reflexões sobre a Lei Federal $\mathrm{n}^{\mathrm{o}}$ 12.846/2013. Revista de Direito Público da Economia - RDPE. V. 46. Belo Horizonte: Fórum, 2014. Versão obtida digitalmente. P. 131, 170.

DAL POZZO, Antonio Araldo Ferraz, et alli. Lei Anticorrupção: apontamentos sobre a Lei $n^{o}$ 12.846/2013. $2^{\mathrm{a}}$ Ed. São Paulo: Contracorrente, 2015.

DAWAR, Kamala. Entrevista. Cadernos da Escola Paulista de Contas Públicas. V.1. n. 3. São $\quad$ Paulo: $2018 . \quad$ P. $72 . \quad$ Disponível em https://www.tce.sp.gov.br/epcp/cadernos/index.php/CM/article/view/66/54. Acesso em 05.04.2019.

DE SANCTIS, Fausto Martin. Lei anticorrupção e lavagem de dinheiro. Revista dos Tribunais. V. 947/2014. São Paulo: Editora Revista dos Tribunais. Versão obtida digitalmente.

DEL DEBBIO, Alessandra. MAEDA, Bruno Carneiro. AYRES, Carlos Henrique da Silva (Coord.). Temas de anticorrupção e compliance. Rio de Janeiro: Elsevier, 2013.

DELGADO, Malu. Fuzileiro pronto para atirar em Dilma. Jornal Valor Econômico. Publicado em 18.03.2016.

DEMATTÉ, Flávio Rezende. Responsabilização de pessoas jurídicas por corrupção. Belo Horizonte: Fórum, 2015.

DERZI, Mizabel Abreu. Direito tributário, direito penal e tipo. São Paulo: RT, 2008.

DI PIETRO, Maria Sylvia Zanella. Direito Administrativo. $28^{\text {a }}$ Ed. São Paulo: Atlas, 2015.

DIAS, Bruno Fernandes. Responsabilidade de pessoas jurídicas e físicas em matéria de corrupção: o regime jurídico da Lei $\mathrm{n}^{\circ}$ 12.846/2013. Fórum Administrativo - FA. V. 167. Belo Horizonte: Fórum, 2015 Versão obtida digitalmente. P. 20.

DIAS, José Figueiredo. O direito penal entre a sociedade industrial e a sociedade de risco. Doutrinas Essenciais de Direito Penal. Vol. 2. São Paulo: Revista dos Tribunais, 2010. Versão obtida digitalmente. P. 269, 298.

DIAS, José Luiz Pires; PRADO, Patrícia Pontes Passarelli. Responsabilidade civil objetiva no código de defesa do consumidor: um outro ponto de vista. Doutrinas Essenciais de Responsabilidade Civil. Vol. 4. São Paulo: Revista dos Tribunais, 2011. Versão obtida digitalmente. P. 417, 424. 
DINIZ, Maria Helena. Curso de Direito Brasileiro. $1^{\circ}$ V. $21^{a}$ Ed. São Paulo: Saraiva, 2004.

DIP, Ricardo. Tipo objetivo e personalização penal na lei 12.846/2013. Revista dos Tribunais. V. 947/2014. São Paulo: Editora Revista dos Tribunais. Versão obtida digitalmente.

DOBROWOLSKI, Samantha Chantal. Breve nota sobre a lei anticorrupção $e$ a responsabilização de pessoas jurídicas. Revista Eletrônica Consultor Jurídico. Publicado em 02.05.2016.

DOTTI, Renê Ariel. A incapacidade criminal da pessoa jurídica (uma perspectiva do direito brasileiro). Doutrinas Essenciais de Direito Penal Econômico e da Empresa. Vol. 1. São Paulo: Revista dos Tribunais, 2011. Versão obtida digitalmente. P. 1127, 1148.

DOURADO, Ruy Janoni. Acordo de Leniência não é anistia ou perdão. Jornal Valor Econômico. Publicado em 08.09.2015.

DRUMMOND, Carlos. MP 703, a medida necessária. Revista Carta Capital. Publicado em 11.01.2016.

ECO, Umberto. Como se faz uma tese. 13ª Ed. Lisboa: Editorial Presença, 2007.

ERHARD, Werner H.; JENSEN, Michael C.; ZAFFRON, Steve. Integrity: A positive model that incorporates the normative phenomena of morality, ethics and legality. Harvard NOM Research Paper $N^{o}$ 06-11. Março de 2009. Disponível em http://ssrn.com/abstract=920625. Acesso em 20.05.2019.

ESTADOS UNIDOS MEXICANOS. Lei Geral de Responsabilização Administrativa, de 18.07.2016. Disponível em http://www.diputados.gob.mx/LeyesBiblio/pdf/LGRA.pdf. Acesso em 06.04.2019.

ESTELITTA, Heloísa. TANGERINO, Davi. Como punir pessoas jurídicas por ilícitos? Jornal Valor Econômico. Publicado em 09 de novembro de 2015.

FABRETTI, Humberto Barrionuevo. Panorama crítico da lei anticorrupção (Lei 12.846/2013). Revista dos Tribunais. V. 947/2014. São Paulo: Editora Revista dos Tribunais. Versão obtida digitalmente.

FACHIN, Roberto Costa; PENA, Roberto Patrus Mundim; CARVALHO NETO, Antônio. Liberdade da empresa cidadã e liberdade na empresa cidadã: uma discussão epistemológica. Mimeo. V Encontro de Estudos Organizacionais da ANPAD. Belo Horizonte: 2008. 
Disponível em http://www.anpad.org.br/admin/pdf/TC\%20EnEO351.pdf. Acesso em 10.02.2019.

FAZZIO JUNIOR, Waldo. Improbidade Administrativa. São Paulo: Atlas, 2014.

FEIJÓO SANCHES, Bernardo José. Cuestiones basicas sobre la responsabilidad penal de las personas juridicas, de otras personas morales y de agrupaciones y asociaciones de personas. Doutrinas Essenciais de Direito Penal. Vol. 3. São Paulo: Revista dos Tribunais, 2010. Versão obtida digitalmente. P. 73, 113.

FERNANDES, Jorge Ulisses Jacoby; NASCIMENTO, Melilo Dinis do. Lei anticorrupção empresarial - Aspectos críticos à lei no 12.846/2013. Belo Horizonte: Fórum, 2014.

FERNÁNDEZ-VALMAYOR, José Luis Carro. Ética pública y normativa administrativa. Revista de Administración Pública. N. 181. Madrid, 2010. P. 9, 37.

FERRAZ JÚNIOR, Tércio Sampaio. Normas gerais e competência concorrente: uma exegese do art. 24 da Constituição Federal. Revista da Faculdade de Direito da USP. N. 90. São Paulo, 1995. P. 245, 251.

FERRAZ, Luciano. Reflexões sobre a Lei ${ }^{\circ}$ 12.846/2013 e seus impactos nas relações públicos-privadas - Lei de improbidade empresarial e não lei anticorrupção. RBDP. V. 47. Belo Horizonte: Fórum, 2014. Versão obtida digitalmente. P. 33,43.

FERRAZ, Manoel Martins de Figueiredo. A corrupção eleitoral no direito romano. Revista de Direito Administrativo. V. 172. Rio de Janeiro: Renovar, 1988. P. 37,44.

FERRAZ, Sergio (coord.). Direito e liberdade. São Paulo: IASP, 2017.

FERRAZ, Sergio. Corrupção: algumas reflexões. RDPE. Belo Horizonte, ano 7, $\mathrm{n}^{\circ}$ 26, 2009. Versão obtida digitalmente. Acesso em 09.10.2015.

FERRAZ, Sergio. O Direito Administrativo reconstruído a partir da ideia de liberdade e da primazia do indivíduo. In FERRAZ, Sergio (coord.). Direito e liberdade. São Paulo: IASP, 2017. P. 353, 363.

FERRAZ, Sergio. Parecer não publicado. 20 de novembro de 2002.

FERRAZ, Sergio; DALLARI, Adílson Abreu. Processo administrativo. $3^{\mathrm{a}}$ ed. São Paulo: Malheiros, 2012. 
FERRAZ, Sergio; SAAD, Amauri Feres. Uma declaração de princípios. In FERRAZ, Sergio (coord.). Direito e liberdade. São Paulo: IASP, 2017, P. 15, 34.

FERRAZ. Sergio. Instrumentos de defesa dos administrados. In: BANDEIRA DE MELLO, Celso Antônio (coord.). Curso de direito administrativo. São Paulo: RT, 1986. P. 154, 174.

FERREIRA FILHO, Manoel Gonçalves. A corrupção como fenômeno social e político. RDA. V. 185. Rio de Janeiro: Renovar, 1991. P. 1,18.

FERREIRA, Daniel. Sanções administrativas. São Paulo: Malheiros, 2001.

FERREIRA, Daniel. Teoria geral da infração administrativa a partir da Constituição Federal de 1988. Belo Horizonte: Fórum, 2009.

FERREIRA, Keila Pacheco. Responsabilidade civil preventiva. Tese (Doutorado em Direito Civil). 2014. Faculdade de Direito - Universidade de São Paulo, São Paulo.

FIANDACA, Giovanni. O bem jurídico como problema teórico e como critério de política criminal. Doutrinas Essenciais de Direito Penal. Vol. 2. São Paulo: Revista dos Tribunais, 2010. Versão obtida digitalmente. P. 523, 563.

FIGUEIREDO, Marcelo. Controle da moralidade na constituição. $1^{\mathrm{a}}$ Ed. $2^{\mathrm{a}}$ Tiragem. São Paulo: Malheiros, 1999.

FILGUEIRAS, Fernando de Barros. Notas críticas sobre o conceito de corrupção: um debate com juristas, sociólogos e economistas. Revistas de Informação Legislativa. N. 164. Brasília: 2004. P. 125, 148.

FORIGO, Camila Rodrigues. GONÇALVES, Oksandro Osdival. A aplicabilidade das sanções previstas na lei anticorrupção empresarial (lei 12.846/2013): uma análise a partir das fraudes envolvendo o Metrô de São Paulo. Revista Brasileira de Ciências Criminais. V. 115/2015. São Paulo, 2015. P. 337, 366.

FORTINI, Cristiana. Princípio da segurança jurídica e a lei no 9.784/99. In VALIM, Rafael; OLIVEIRA, José Roberto Pimenta; DAL POZZO, Augusto Neves (Coord.). Tratado sobre o princípio da segurança jurídica no direito administrativo. Belo Horizonte: Fórum, 2013. P. $461,474$.

FRANÇA, Rodrigo Dumans. A teoria do risco aplicada à responsabilidade objetiva. 2009. Dissertação (Mestrado em Direito Civil) - Faculdade de Direito, Universidade de São Paulo, São Paulo. 
FRANÇA, Rubens Limongi. As raízes da responsabilidade aquiliana. Doutrinas essenciais de responsabilidade civil. Vol. 1. São Paulo: RT, 2011.

FRANÇA, Vladimir da Rocha. Processo administrativo sancionador na Lei Federal $\mathrm{n}^{\mathrm{o}}$ 9.785/1999. In NOHARA, Irene Patrícia; MORAES FILHO, Marco Antonio Praxedes de (org.). Processo administrativo: temas polêmicos da Lei $n^{\circ}$ 9.784/99. São Paulo: Atlas, 2011. P. 263, 278.

FRANCO SOBRINHO, Manoel de Oliveira. Introdução à teoria do órgão no direito administrativo. Revista de Direito Administrativo, Rio de Janeiro, v. 98, P. 17, 36, set. 1969. Disponível em: http://bibliotecadigital.fgv.br/ojs/index.php/rda/article/view/33388;

FRANCO SOBRINHO, Manoel de Oliveira. O controle da moralidade administrativa. São Paulo: Saraiva, 1974.

FRAZÃO, Ana. Corrupção e compliance: um exame da questão à luz das relações entre direito, ética e moral. In LAMACHIA, Cláudio; PETRARCA, Carolina (Org). Compliance: essência e efetividade. Brasília: OAB, Conselho Federal, 2018. P. 195, 201.

FRAZÃO, Ana. Responsabilidade de pessoas jurídicas por atos de corrupção: reflexão sobre os critérios de imputação. In FORTINI, Cristiana (Coord.). Corrupção e seus múltiplos enfoques jurídicos. Belo Horizonte: Fórum, 2018. P. 35, 56.

FREITAS, Juarez. Do princípio da probidade administrativa e de sua máxima efetivação. Revista de Informação Legislativa. N. 129. Brasília: 1996. P. 51, 65.

FREITAS, Juarez. O controle dos atos administrativos. São Paulo: Malheiros, 1997.

FREITAS. Arystóbulo de Oliveira. Responsabilidade civil objetiva no código de defesa do consumidor. Revista de Direito do Consumidor - RDC. Vol. 11/1994. São Paulo: Revista dos Tribunais. Versão obtida digitalmente. P. 101, 127.

FULLER, Lon L.. Positivism and fidelity to law - A reply to Professor Hart. Harvard Law Review, V. 71. No 4. Fevereiro de 1958. P. 630, 672. Disponível em www.jstor.org/stable/1338226. Acesso em 01.07.2019.

FULLER, Lon L..The morality of law. New Haven: Yale University Press, 1964.

FUNDAÇÃO GETÚLIO VARGAS. Lei Anticorrupção: transparência e boas práticas. Cadernos FGV Projetos. Abril de 2016. No 27. 
FURTADO, Lucas Rocha. As raízes da corrupção no Brasil - Estudo de casos e lições para o futuro. Belo Horizonte: Fórum, 2015.

GABARDO, Emerson. CASTELLA, Gabriel Morettini e. A nova lei anticorrupção e a importância do compliance para as empresas que se relacionam com a Administração Pública. Revista A\&C. N. 60. Belo Horizonte, 2015. P. 129, 147.

GALVÃO, Leonardo Vasconcellos Braz. A inconstitucionalidade do art. 25 da Lei Anticorrupção. Revista Brasileira de Estudos da Função Pública - RBFEP. N. 11. Belo Horizonte, 2015. P. 215, 229.

GAN BUSINESS ANTI-CORRUPTION PORTAL. Sapin II Compliance Guide. Disponível em https://www.business-anti-corruption.com/compliance-quick-guides/sapin-iicompliance-guide/. Acesso em 06.04.2019;

GARCIA DE ENTERRIA, Eduardo; FERNANDEZ, Tomás-Ramón. Curso de derecho administrativo. T. II. Madrid: Civitas, 1977.

GARCIA, Emerson. A corrupção. Uma visão jurídico-sociológica. Revista de Direito Administrativo. V. 233. Rio de Janeiro: FGV, 2003. P. 103,139.

GARCIA, Emerson. A moralidade administrativa e sua densificação. Revista de Informação Legislativa. N. 155. Brasília: 2002. P. 153, 173.

GARCIA, Emerson. De volta à teoria da corrupção: Dobel e as estruturas sociais primárias. Revista de Direito Constitucional e Internacional. V. 90/2015. São Paulo: RT, 2015. P. 77, 89.

GARCIA, Emerson; ALVES, Rogério Pacheco. Improbidade administrativa. $8^{\text {a }}$ Ed. São Paulo: Saraiva, 2015.

GARCIA, Maria. Corrupção do Estado e a constituição de 1988. Reforma política e o recall. Revista dos Tribunais. V. 967/2016. São Paulo: Editora Revista dos Tribunais. Versão obtida digitalmente. P. 45, 50.

GARCIA, Maria. De volta à teoria da corrupção: Dobel e as estruturas sociais primárias. Revista de Direito Constitucional e Internacional. V. 90/2015. São Paulo, 2015. P. 77, 89.

GIOVANINI, Wagner. Mecanismo de integridade ou arma para proteção?. In BORGES DE PAULA, Marco Aurélio; CASTRO, Rodrigo Pironti Aguirre de. (Coord.). Compliance, gestão de riscos e combate à corrupção. Belo Horizonte: Fórum, 2018. P. 71, 88. 
GIOVANINI, Wagner. Programas de compliance e anticorrupção: importância e elementos essenciais. In BORGES DE PAULA, Marco Aurélio; CASTRO, Rodrigo Pironti Aguirre de. (Coord.). Compliance, gestão de riscos e combate à corrupção. Belo Horizonte: Fórum, 2018. P. 53, 70.

GOMES, Orlando. Responsabilidade civil. atual. por Edvaldo Brito. Rio de Janeiro: Forense, 2011.

GÓMES-JARA DÍEZ, Carlos. La culpabilidad penal de la empresa. Madrid: Marcial Pons, 2005.

GÓMEZ-JARA DIEZ, Carlos. A responsabilidade penal da pessoa jurídica e o dano ambiental. Trad. Cristina Reindolff da Motta. Porto Alegre: Livraria do Advogado, 2013.

GÓMEZ-JARA DÍEZ, Carlos. Imputabilidade de las personas jurídicas. Revista Brasileira de Ciências Criminais - RBCC. Vol. 63/2006. São Paulo: Revista dos Tribunais. Versão obtida digitalmente. P. 47,75.

GÓMEZ-JARA DÍEZ, Carlos. Responsabilidad penal de los directivos de empresa em virtude de su domínio de la organización - algunas consideraciones críticas. Revista Brasileira de Ciências Criminais - RBCC. Vol. 68/2007. São Paulo: Revista dos Tribunais. Versão obtida digitalmente. P. 141,181.

GONÇALVES, Alexandre Manoel. BUSNELLO, Priscilla de Castro. Corrupção: questões éticas e jurídicas. Revista dos Tribunais. V. 947/2014. São Paulo: Editora Revista dos Tribunais. Versão obtida digitalmente. P. 425.

GONÇALVES, Antonio Baptista. A responsabilidade penal da pessoa jurídica e a relação da lei dos crimes ambientais com o novo código civil e o código de defesa do consumidor. Doutrinas Essenciais de Direito Penal Econômico e da Empresa. Vol. 3. São Paulo: Revista dos Tribunais, 2011. Versão obtida digitalmente. P. 771, 793.

GONÇALVES, Benedito. A Lei12.846/2013 e a tutela do direito material coletivo da probidade na administração pública. In ARAÚJO, Raul; NOBRE JÚNIOR, Edilson Pereira; CARRÁ, Bruno Leonardo Câmara (org). Estudos sobre a administração pública e o combate à corrupção: desafios em torno da Lei 12.846/2013. Brasília: Centro de Estudos Judiciários do Conselho da Justiça Federal, 2018. P. 32, 43.

GORDILLO, Augustín. Las raíces legales de la corrupción: O de cómo el derecho público fomenta la corrupción em lugar de combatirla. Cuadernos de la RPA. Editorial RAP, Buenos Aires, 2007. Diálogos con Augustin Gordillo. Versão obtida digitalmente. 
GORDILLO, Augustín. Um corte transversal al derecho administrativo: la convención interamericana contra la corrupción. Versão obtida digitalmente.

GRAF, Ana Cláudia Bento; FIGUEREDO, Guilherme José Purvin de. Proteção do meio ambiente e do erário: um novo paradigma para a advocacia pública. In BENJAMIN, Antonio Herman; FIGUEIREDO, Guilherme José Purvin de (coord.). Direito ambiental e as funções essenciais à justiça: o papel da advocacia de estado e da defensoria pública na proteção do meio ambiente. São Paulo: RT, 2011. P. 147, 157.

GRAU, Eros Roberto. Ensaio e discurso sobre a interpretação/aplicação do Direito. $5^{\text {a }}$ Ed. São Paulo: Malheiros, 2009.

GRAU, Eros. Direito posto e pressuposto. 9a Ed. São Paulo: Malheiros, 2014.

GRECO FILHO, Vicente; RASSI, João Daniel. O combate à corrupção e comentários à lei de responsabilidade de pessoas jurídicas. São Paulo: Saraiva, 2015.

GRECO, Luís. A relação entre o direito penal e o direito administrativo no direito penal ambiental: uma introdução aos problemas da acessoriedade administrativa. Doutrinas Essenciais de Direito Penal. Vol. 8. São Paulo: Revista dos Tribunais, 2010. Versão obtida digitalmente. P. 61, 97.

GREGORI, Maria Stella. A responsabilidade das empresas nas relações de consumo. Doutrinas Essenciais de Direito Penal Econômico e da Empresa. Vol. 3. São Paulo: Revista dos Tribunais, 2011. Versão obtida digitalmente. P. 873, 884.

GRINOVER, Ada Pellegrini. Aspectos processuais da responsabilidade penal da pessoa jurídica. Doutrinas essenciais de Direito Ambiental. V. 5. São Paulo: RT, 2011. P. 543, 561.

GUARAGNI, Fábio André. Disposições gerais: comentários aos artigos $1^{\circ}$ a $4^{\circ}$. In CAMBI, Eduardo; GUARAGNI, Fábio André. Lei Anticorrupção. São Paulo: Almedina, 2014. P. 47, 101.

GUARAGNI, Fábio André; CHIAMULERA, Andressa. Autorresponsabilidade penal da pessoa jurídica em crimes ambientais: aspectos práticos da atuação do Ministério Público. Mimeo.

Disponível em http://www.ceaf.mppr.mp.br/arquivos/File/Teses_2015/FabioGuaragni_AndressaChiamule ra_Autorresponsabilidade_Penal_da_Pessoa_Juridica_em_Crimes_Ambientais.pdf. Acesso em 20.02.2018. 
GUARDIA, Gregório Raphael S.. Princípios processuais no Direito Administrativo Sancionador: um estudo à luz das garantias constitucionais. Revista da Faculdade de Direito da Universidade de São Paulo. V. 109. São Paulo: USP, 2014. P. 773, 793.

GUERINI, Caroline Gonçalves. Responsabilidade da pessoa jurídica e o compliance ambiental. 2017. Monografia (Especialização em Direito Ambiental) - Setor de Ciências Agrárias, Universidade Federal do Paraná - UFPR, Curitiba.

GUIMARÃES, Fernando Vernalha. Mudanças no acordo de leniência. Jornal Valor Econômico. Publicado em 22 de abril de 2016.

GUIMARÃES, Rodrigo Régnier Chemin. Da responsabilização administrativa. Comentários aos artigos $6^{\circ}$ e $7^{\circ}$. In CAMBI, Eduardo; GUARAGNI, Fábio André. Lei Anticorrupção. São Paulo: Almedina, 2014.P. 137, 161.

GÜNTHER, Klaus. A culpabilidade do direito penal atual e no futuro. Doutrinas Essenciais de Direito Penal. Vol. 3. São Paulo: Revista dos Tribunais, 2010. Versão obtida digitalmente. P.769, 786.

GUSTIN, Miracy Barbosa de Sousa. DIAS, Maria Tereza Fonseca. (Re)pensando a pesquisa jurídica: teoria e prática. $2^{\mathrm{a}}$ Ed. Belo Horizonte: Del Rey, 2006.

HAMMERSCHMIDT, Denise. Sanção penal e pessoa jurídica na lei dos crimes ambientais brasileira: algumas considerações. Doutrinas Essenciais de Direito Penal Econômico e da Empresa. Vol. 3. São Paulo: Revista dos Tribunais, 2011. Versão obtida digitalmente. P. $115,145$.

JONAS, Hans. O princípio responsabilidade: ensaio de uma ética para a civilização tecnológica. Trad. Marijiane Lisboa e Luiz Barros Montez. Rio de Janeiro: Contraponto, 2006.

HART, H. L. A.. Book Reviews. The morality of law by Lon L. Fuller. Harvard Law Review. V. 78. No 6. Abril de 1965. P. 1281, 1296. Disponível em www.jstor.org/stable/1338941. Acesso em 01.07.2019. Acesso em 02.05.2019.

HART, H. L. A.. Positivism and the separation of law and morals. Harvard Law Review. V. 71. $\mathrm{N}^{\mathrm{o}}$ 4. Fevereiro de 1958. P. 593, 629. Disponível em http://www.jstor.org/stable/1338225. Acesso em 01.07.2019. Acesso em 02.05.2019.

HAURIOU, Maurice. A teoria da instituição e da fundação. Ensaio de vitalismo social. Trad. José Ignácio Coelho Mendes Neto. Porto Alegre: Sérgio Fabris, 2009; 
HAZARD, John N.. Soviet socialism and embezzlement. Washington Law Review \& State Bar Journal. V. 26 (301). Issue 4. Janeiro de 1951. Disponível em https://digitalcommons.law.uw.edu/cgi/viewcontent.cgi?article=2959\&context=wlr.

Acesso em 18.07.2019.

HEINEN, Juliano. Comentários à Lei Anticorrupção. Belo Horizonte: Fórum, 2015.

HENKES, Silviana L. Os novos contornos da tutela jurídica na sociedade de risco: dano ambiental futuro e risco do dano. Revista de direito difusos. Ano VIII, Vol. 43. 2007. P. 77, 108.

HODGES, Christopher. Law and Corporate behaviour. Oxford and Portland, Oregon: Hart, 2015 .

HODGES, Christopher; STEINHOLTZ, Ruth. Ethical business practice and regulation. Oxford and Portland, Oregon: Hart, 2017.

HUFFINGTON POST. "China's "Fox Hunt" makes great achievements". Disponível em https://www.huffingtonpost.com/entry/chinas-fox-hunt-makes-great-

achievements_us_58f61286e4b0156697225299. Acesso em 04.12.2018.

HUNGRIA, Nélson. Comentários ao Código Penal. $2^{\text {a }}$ Ed. Vol. IX. Rio de Janeiro: Forense, 1959.

HUNGRIA, Nélson. Ilícito administrativo e ilícito penal. RDA. V. 1. Rio de Janeiro: Renovar, 1945. P. 24, 31.

HUNTINGTON, Samuel. Political order in changing societies. Yale University. 1968. Disponível em https://projects.iq.harvard.edu/gov2126/files/huntington_political_order_changing_soc.pdf. Acesso em 02.10.2018.

HUSEK, Carlos Roberto. Curso de direito internacional público. 10ª Ed. São Paulo: LTr, 2010.

JACOBY, Jorge Ulisses; COSTA, Karina Amorim. Breves comentários à lei da responsabilização administrativa e civil de pessoas jurídicas pela prática de atos contra a Administração Pública, nacional ou estrangeira. In NASCIMENTO, Melillo Diniz (org). Lei anticorrupção empresarial. Aspectos críticos à Lei $n^{o}$ 12.846/2013. Belo Horizonte: Fórum, 2014. P. 29, 58.

JESUS, Damásio E. de. Código penal anotado. $5^{\text {a }}$ Ed. São Paulo: Saraiva, 1995. 
JORGE, Flávio Cheim. A tutela da probidade administrativa: crime de responsabilidade ou ação civil de improbidade administrativa? Doutrinas Essenciais de Responsabilidade Civil. Vol. 6. São Paulo: Revista dos Tribunais, 2011. Versão obtida digitalmente. P. 795, 806.

JORGE, Flávio Cheim. Responsabilidade civil por danos difusos e coletivos sob a ótica do consumidor. Doutrinas Essenciais de Responsabilidade Civil. Vol. 4. São Paulo: Revista dos Tribunais, 2011. Versão obtida digitalmente. P. 437, 494.

JOSSERAND, Louis. Evolução da responsabilidade civil. In. Revista Forense, V. LXXXVI, Fascículo 454. Rio de Janeiro: Forense, 1941. P. 548, 559;

JUNIOR, Nelson Nery. Os princípios gerais do código brasileiro de defesa do consumidor. Revista de Direito do Consumidor - RDC. Vol. 3/1992. São Paulo: Revista dos Tribunais. Versão obtida digitalmente. P. 44,77.

KINDHAÜSER, Urs. Culpabilidad juridico-penal en el Estado Democratico de Derecho. Doutrinas Essenciais de Direito Penal. Vol. 3. São Paulo: Revista dos Tribunais, 2010. Versão obtida digitalmente. P. 1005, 1022.

KIRCHNER, Felipe. A responsabilidade civil objetiva no art. 927, parágrafo único, do CC/02. Doutrinas Essenciais de Responsabilidade Civil. Vol. 2. São Paulo: Revista dos Tribunais, 2011. Versão obtida digitalmente. P. 617, 657.

KRAMER, Evane Beiguelman. Macunaíma e o combate à corrupção. Jornal Valor Econômico. Publicado em 22.01.2016.

KUYVEN, Fernando. Aplicação ultraterritorial da lei anticorrupção. Revista de Direito Empresarial. V. 4/2014. São Paulo: Editora Revista dos Tribunais. Versão obtida digitalmente.

LACERDA, Fernando Hideo I. MP 703 é um passo à racionalização dos acordos de leniência. Revista Eletrônica Consultor Jurídico. Publicado em 14.01.2016.

LAÉRCIO, Diógenes. Vidas e doutrinas dos filósofos ilustres. X (30). Trad. Mário da Gama Kury. Brasília: Editora Universidade de Brasília, 2008.

LAFER, Celso. Desenvolvimento sustentável e novas implicações da responsabilidade. Café Filosófico CPFL (Parceria entre a TV Cultura e o Instituto CPFL). São Paulo: TV Cultura, 2018. Duração 48'28”. Cm https://www.youtube.com/watch?v=BOERCUMNwTA. Acesso em 22.05.2018. 
LANFREDI, Geraldo Ferreira. A objetivação da teoria da responsabilidade civil e seus reflexos nos danos ambientais ou no uso anti-social da propriedade. Doutrinas Essenciais de Responsabilidade Civil. Vol. 7. São Paulo: Revista dos Tribunais, 2011. Versão obtida digitalmente. P. 407, 421.

LEAL, Rogério Gesta. A nova lei anticorrupção empresarial no Brasil: novo marco regulatório às responsabilidades das pessoas jurídicas por atos atentatórios aos bens públicos. Interesse Público - IP. V. 88. Belo Horizonte: Fórum, 2014. Versão obtida digitalmente. P. 25,54.

LEAL, Rogério Gesta. Os bens jurídicos tutelados na Lei de Improbidade Administrativa e o dever de correspondência dos agentes públicos em face das responsabilidades jurídicas consectárias. Revista de Direito Administrativo e Constitucional. N. 53. Belo Horizonte, 2013. Versão obtida digitalmente.

LEFF, Nathaniel. Economic development through bureaucratic corruption. American Behavioral Scientist, vol. 8, n. 3, nov.1964. P. 8, 14.

LEIGH, David; EVANS, Rob. BAE: secret papers reveal threats from Saudi prince. The Guardian. Publicado em 15.02.2008. Disponível em https://www.theguardian.com/world/2008/feb/15/bae.armstrade.

LEIGH, David; EVANS, Rob. Blair called for BAE inquiry to be halted. The Guardian. Publicado em 22.12.2007. Disponível em https://www.theguardian.com/baefiles/story/0, 2231496,00.html.

LEITE, Maurício Silva. NOBRE, Eduardo Maffia Queiroz. Responsabilidade solidária por atos de corrupção. Revista dos Tribunais. V. 947/2014. São Paulo: Editora Revista dos Tribunais. Versão obtida digitalmente.

LEONARDO, Rodrigo Xavier. Revisitando a teoria da pessoa jurídica na obra de J. Lamartine Corrêa de Oliveira. Revista da Faculdade de Direito UFPR, Curitiba, PR, Brasil, v. 46, dez. 2007. ISSN 2236-7284. Disponível em: https://revistas.ufpr.br/direito/article/view/14977. Acesso em 16.01.2019.

LEUZINGER, Márcia Dieguez; SANTANA, Paulo Campanha. Responsabilidade administrativa por danos causados ao meio ambiente. Revista de Direito Ambiental. Vol. 87/2017. São Paulo: Revista dos Tribunais, 2017. Versão obtida digitalmente. P. 249, 269.

LIMA, Alvino. Culpa e risco. $2^{\mathrm{a}}$ Ed. atual. por Ovídio Rocha Barros Sandoval. São Paulo: RT, 1998. 
LIMA, Thadeu Augimeri de Goes. Processo penal e interesses supraindividuais (diálogos com o processo coletivo no contexto de pluritutela jurídica dos interesses difusos). Tese (Doutorado em Direito Penal). 2018. Faculdade de Direito - Universidade de São Paulo, São Paulo.

LIVIANU, Roberto. Corrupção - Incluindo a Lei Anticorrupção. São Paulo: Quartier Latin, 2014.

LIVIANU, Roberto. OLIVEIRA, Julio Marcelo. Medida provisória 703 é uma verdadeira aberração jurídica afrontosa à CF. Revista Eletrônica Consultor Jurídico. Publicado em 11.01.2016.

LLOVET, Tomás Font i. La protección del domínio publico en la formación del derecho administrativo español: potestad sancionadora y ressarcimento de daños. Revista de Administración Pública. N. 123. 1990. P. 7, 81.

LOPEZ, Teresa Ancona. Princípio da precaução e evolução da responsabilidade civil. São Paulo: Quartier Latin, 2010.

LOUREIRO, Maria Fernanda. Responsabilidade penal da pessoa jurídica. A teoria do delito para a incriminação da empresa. Curitiba: Juruá, 2017.

LOZANO, Blanca. La responsabilidade de la persona juridica en el ambito sancionador administrativo. Revista de Administración Publica. N. 129. 1992. P. 211, 239.

LUCON, Paulo Henrique dos Santos. Devido processo legal substancial. Revista de doutrina da $\quad 4^{a} \quad$ Região, $\mathrm{n}^{\mathrm{o}} \quad 15, \quad$ Nov: 2006. Disponível em https://bdjur.stj.jus.br/jspui/bitstream/2011/60849/devido processo legal substancial.pdf. Acesso em 30.01.2018;

LUCON, Paulo Henrique dos Santos. Procedimento e sanções na lei anticorrupção (lei 12.846/2013). Revista dos Tribunais. V. 947/2014. São Paulo: Editora Revista dos Tribunais. Versão obtida digitalmente.

LUNA, Everardo da Cunha. Bem jurídico (Direito Penal). In FRANÇA, R. L. (Coord.). Enciclopédia Saraiva do Direito. V. 10. São Paulo: Saraiva, 1977. P. 458, 470.

LUZ, Yuri Corrêa da. O combate à corrupção entre direito penal e direito administrativo sancionador. Doutrinas Essenciais de Direito Penal Econômico e da Empresa. V. 4. São Paulo: RT, 2011. P. 1079, 1120. 
MACHADO, Ana Maria França. O sistema brasileiro anticorrupção: internacionalização do Direito e variantes nacionais. 2010. Dissertação (Mestrado em Direito) - Faculdade de Direito, Universidade de São Paulo, São Paulo.

MACHADO, Fábio Guedes de Paula. Reminiscências da responsabilidade penal da pessoa jurídica e sua efetividade. Doutrinas Essenciais de Direito Penal. Vol. 3. São Paulo: Revista dos Tribunais, 2010. Versão obtida digitalmente. P. 361, 386.

MACHADO, Hugo de Brito. Curso de direito tributário. 29a Ed. São Paulo: Malheiros, 2008.

MACHADO, Maíra Rocha. A responsabilidade civil é independente da criminal, em termos: a propósito da contribuição da criminologia positivista à transformação da responsabilidade civil. Revista Brasileira de Ciências Criminais - RBCC. Vol. 65/2007. São Paulo: Revista dos Tribunais. Versão obtida digitalmente. P. 317, 344.

MACHADO, Paulo Affonso Leme. Direito ambiental brasileiro. 24 ${ }^{\mathrm{a}}$ Ed. São Paulo: Malheiros, 2016.

MADRUGA, Antenor. Corrupção da pessoa jurídica para apuração do ato de corrupção: investigação apropriada? Revista dos Tribunais. V. 947/2014. São Paulo: Editora Revista dos Tribunais. Versão obtida digitalmente.

MAEDA, Bruno Carneiro. Programas de compliance anticorrupção: importância e elementos essenciais. In DEL DEBBIO, Alessandra; MAEDA, Bruno Carneiro; AYRES, Carlos Henrique da Silva. Temas de anticorrupção \& compliance. São Paulo: Campus Jurídico, 2013. P. 167, 202.

MANCUSO, Rodolfo de Camargo. Interesses difusos e coletivos. Doutrinas Essenciais de Direito do Consumidor. Vol. 6. São Paulo: Revista dos Tribunais, 2011. Versão obtida digitalmente. P. 321, 344.

MARÇAL, Sérgio Pinheiro. Código de defesa do consumidor: definições, princípios e o tratamento da responsabilidade civil. Doutrinas Essenciais de Responsabilidade Civil. Vol. 4. São Paulo: Revista dos Tribunais, 2011. Versão obtida digitalmente. P. 363, 378.

MARQUES NETO, Floriano de Azevedo; FREITAS, Rafael Véras de. O artigo 22 da LINDB e os novos contornos do Direito Administrativo Sancionador. Consultor Jurídico. 25 julho de 2018. Disponível em https://www.conjur.com.br/2018-jul-25/opiniao-artigo-22lindb-direito-administrativo-sancionador\#_ftn8. Acesso em 28.05.2019. 
MARQUES, Cláudia Lima. Contratos no Código de Defesa do Consumidor. $6^{\text {a }}$ Ed. São Paulo: RT, 2011.

MARQUES, Cláudia Lima. Diálogo entre o código de defesa do consumidor e o novo código civil. Do diálogo das fontes no combate às cláusulas abertas. Doutrinas Essenciais de Responsabilidade Civil. Vol. 4. São Paulo: Revista dos Tribunais, 2011. Versão obtida digitalmente. P. 57, 90.

MARRARA, Thiago. Acordos de leniência no processo administrativo brasileiro: modalidades, regime jurídico e problemas emergentes. RDDA/USP. V. 2. N. 2. Ribeirão Preto, 2015. P. 509, 527.

MARTINS JÚNIOR, Wallace Paiva. Controle da Administração Pública pelo Ministério Público. Ministério Público defensor do povo. São Paulo, Ed. Juarez de Oliveira, 2002.

MARTINS JÚNIOR, Wallace Paiva. Probidade administrativa. São Paulo: Saraiva, 2009.

MARTINS, Ricardo Marcondes. Abuso de direito e a constitucionalização do direito privado. São Paulo: Malheiros, 2010.

MARTINS-COSTA, Judith. A Proteção da Legítima Confiança nas Relações Obrigacionais entre a Administração e os Particulares. Revista da Faculdade de Direito da UFGRS. V. 22. Porto Alegre: Set/2002. P. 228, 258.

MASAGÃO, Mário. Curso de Direito Administrativo. $3^{\text {a }}$ Ed. São Paulo: Max Limonad, $[\mathrm{n} / \mathrm{d}]$.

MATTOS, Mauro Roberto Gomes. O particular e a lei de improbidade administrativa (mimeo). Disponível em http://gomesdemattos.com.br/artigos/O_PARTICULAR_E_A_LEI_DE_IMPROBIDADE_ ADMINISTRATIVA.pdf. Acesso em 24.03.2018.

MAURÍCIO JÚNIOR, Alceu; MORAES, Francisco de Assis Basílio de; BERTOLDE, Ingridy Silva. A Lei da Ficha Limpa e o princípio da moralidade na Administração Pública. Fórum Administrativo - FA, Belo Horizonte, ano 14, n. 156, P. 21, 33, fev. 2014.

MAURO, Paolo. Corruption and growth. The Quartely Journal of Economics, vol. 110, n. 3, ago, 1995, P. 681, 712. Disponível em http://homepage.ntu.edu.tw/ kslin/macro2009/Mauro\%201995.pdf. Acesso em 03.12.2018.

MAXIMILIANO, Carlos. Hermenêutica e aplicação do direito. $3^{\text {a }}$ Ed. São Paulo: Freitas Bastos, 1961. 
MAYER, Otto. Derecho administrativo alemán. T. I. Buenos Aires: Depalma, [n/d].

MAZZILLI, Hugo Nigro. A defesa dos interesses difusos em juízo: meio ambiente, consumidor, patrimônio cultural, patrimônio público e outros interesses. $16^{\mathrm{a}}$ Ed. São Paulo: Saraiva, 2003.

MEDAUAR, Odette. Direito administrativo moderno. São Paulo: RT, 2015.

MEIRELLES, Hely Lopes. Direito administrativo brasileiro. Atual. por Délcio Balestero Aleixo e José Emmanuel Burle Filho. 39ª Ed. São Paulo: Malheiros, 2013.

MELlO, Rafael Munhoz de. Princípios constitucionais de direito administrativo sancionador. São Paulo: Malheiros, 2007.

MENDES, Gilmar Ferreira. BRANCO, Paulo Gustavo Gonet. Curso de Direito Constitucional. $6^{\text {a }}$ Ed. São Paulo: Saraiva, 2011.

MILARÉ, Edis. Direito do ambiente. 10ª Ed. São Paulo: RT, 2015.

MILESKI, Helio Saul. Corrupção. Aspectos jurídicos, políticos e econômicos. Interesse Público, nº 19, 2003. P. 237, 250.

MIR PUIG, Santiago; BREIER, Ricardo. Significado e alcance da imputação objetiva em direito penal. Doutrinas Essenciais de Direito Penal. Vol. 2. São Paulo: Revista dos Tribunais, 2010. Versão obtida digitalmente. P. 1379, 1403.

MIRANDA, Jorge. Sobre a reserva constitucional da função legislativa. Perspectivas constitucionais nos 20 anos da Constituição de 1976. V. II. Coimbra: Coimbra Editora, 1997. P. 883, 906.

MIRANDA, Luiz Fernando. Unificando os conceitos de corrupção. Revista Brasileira de Ciência Política. No 25. Brasília: 2018. P. 237, 272.

MISSALI, Guilherme Teno Castilho. Lei 12.846/2013: apontamentos sobre o programa de integridade e a sua importância para o ambiente da ética e conformidade empresarial. Revista de Direito Empresarial. V. 9/2015. São Paulo: RT, 2015. P. 313, 336.

MOLINÉ, José Cid. Garantias y sanciones (argumentos contra la tesis de la identidad de garantías entre las personas punitivas). Revista de Administración Pública. N. 140. 1996. P. $131,172$. 
MORAES, Germana de Oliveira. Controle jurisdicional da Administração Pública. $2^{\mathrm{a}}$ Ed. São Paulo: Dialética, 1999.

MORAES, Rodrigo Iennaco. Considerações sobre a responsabilidade criminal das pessoas jurídicas. Doutrinas Essenciais de Direito Penal Econômico e da Empresa. Vol. 1. São Paulo: Revista dos Tribunais, 2011. Versão obtida digitalmente. P. 1185, 1197.

MOREIRA NETO, Diogo de Figueiredo. Curso de direito administrativo. $15^{\mathrm{a}}$ Ed. Rio de Janeiro: Forense, 2009.

MOREIRA NETO, Diogo de Figueiredo. FREITAS, Rafael Véras de. A juridicidade da lei anticorrupção - reflexos e interpretações prospectivas. Fórum Administrativo - FA. V. 156. Belo Horizonte: Fórum, 2014. Versão obtida digitalmente.

MOREIRA NETO, Diogo de Figueiredo. Moralidade administrativa: do conceito à efetivação. Revista de Direito Administrativo, V. 190. Rio de Janeiro: Renovar, 1992. P. 1, 44.

MOREIRA NETO, Diogo de Figueiredo; FREITAS, Rafael Véras. A juridicidade da Lei Anticorrupção: reflexões e interpretações prospectivas. Fórum Administrativo. Ano 14. N. 156. Belo Horizonte: Fórum, 2014.

MOREIRA NETO, Diogo de Figueiredo; GARCIA, Flávio Amaral. A principiologia no Direito Administrativo Sancionador. Revista Brasileira de Direito Público - RBDP, Belo Horizonte, ano 11, n. 43 out./dez. 2013. Disponível em: http://www.bidforum.com.br/bid/PDI0006.aspx? pdiCntd=98862. Acesso em 10.04. 2015.

MOREIRA, Eduardo Ribeiro. Neoconstitucionalismo e teoria da interpretação. Doutrinas essenciais de Direito Constitucional. V. 7. São Paulo: RT, 2015. P. 69, 87.

MOREIRA, Egon Bockmann. BAGATIN, Andreia Cristina. Lei Anticorrupção e quatro de seus principais temas - responsabilidade objetiva, desconsideração societária, acordos de leniência e regulamentos administrativos. Revista de Direito Público da Economia-RDPE. V. 47. Belo Horizonte: Fórum, 2014. Versão obtida digitalmente.

MOREIRA, Egon Bockmann; CANTO, Mariana Dall'agnol; GUZELA, Rafaella Peçanha. Anticorrupção e suborno no Brasil: melhores práticas anticorrupção. in CARVALHO, André Castro, et alli (Coord.). Manual de Compliance. Rio de Janeiro: Forense, 2019. P. 349, 372.

MUKAI, Toshio. O decreto $\mathrm{n}^{\circ}$ 60.106, de 29 de janeiro de 2014, do Governos do Estado de São Paulo é inconstitucional. Fórum Administrativo - FA. V. 158. Belo Horizonte: Fórum, 2014. Versão obtida digitalmente. P. 67,69. 
NASCIMENTO, Melillo Diniz do. O controle da corrupção no Brasil e a Lei nº 12.846/2013 - Lei Anticorrupção. In NASCIMENTO, Melillo Diniz (org). Lei anticorrupção empresarial. Aspectos críticos à Lei $n^{o}$ 12.846/2013. Belo Horizonte: Fórum, 2014. P. 59, 116.

NASSER, Salem Hikmat. Fontes e normas do direito internacional. São Paulo: Atlas, 2006.

NEGRO, Dalmacio. Sobre la naturaleza de la corrupción política. Revista de Estudios Políticos. N. 199. 1975. P. 103, 148.

NERY JUNIOR, Nelson. Os princípios gerais do código brasileiro de defesa do consumidor. Doutrinas Essenciais de Responsabilidade Civil. Vol. 4. São Paulo: Revista dos Tribunais, 2011. Versão obtida digitalmente.

NERY JUNIOR, Nelson. Responsabilidade civil da administração pública. Aspectos do direito brasileiro positivo vigente: art. $37, \S 6^{\circ}$ da CF/1988 e art. 15, do CC/1916. Doutrinas Essenciais de Responsabilidade Civil. Vol. 6. São Paulo: Revista dos Tribunais, 2011. Versão obtida digitalmente.

NERY JUNIOR, Nelson; NERY, Rosa Maria de Andrade. Coleção doutrinas essências: Responsabilidade Civil. São Paulo: RT, 2010.

NETO, Eloy Rizzo. A Lei Anticorrupção pelo Ministério Público. Jornal Valor Econômico. Publicado em 14.04.2015.

NETO, Miguel Pereira. A lei anticorrupção e a administração pública estrangeira. Revista dos Tribunais. V. 947/2014. São Paulo: Editora Revista dos Tribunais. Versão obtida digitalmente.

NIETO, Alejandro Garcia. Derecho administrativo sancionador. Madrid: Tecnos, 2006.

NOBRE JÚNIOR, Edilson Pereira. Sanções administrativas e princípios de direito penal. Revista de Direito Administrativo. V. 219. Rio de Janeiro, 2000. P. 127, 151.

NORONHA, Fernando. Responsabilidade civil: uma tentativa de ressistematização responsabilidade civil em sentido estrito e responsabilidade negocial; responsabilidade subjetiva e objetiva; responsabilidade subjetiva comum ou normal, e restrita a dolo ou culpa grave; responsabilidade objetiva normal e agravada. Doutrinas Essenciais de Responsabilidade Civil. Vol. 1. São Paulo: Revista dos Tribunais, 2011. Versão obtida digitalmente. P. 145, 195.

NUCCI, Guilherme de Souza. Corrupção e Anticorrupção. Rio de Janeiro: Forense, 2015. 
O ESTADO DE SÃO PAULO. Medida provisória 703. Estadão Projetos Especiais. São Paulo, 2016.

OEA. Declaração de Belém do Pará. AG/DEC 6 (XXIV-O/94). Disponível em http://www.oas.org/es/council/AG/ResDec/. Acesso em 20.11.2018.

OEA. Declaração de Montrouis. Aprovada pela Assembleia Geral em 07 de junho de 1995, por meio do AG/DEC 8 (XXV-O/95).

OEA. Metodología para el seguimiento de la implementación de las recomendaciones formuladas y las disposiciones analizadas en la segunda ronda y para el análisis de las disposiciones de la convención seleccionadas para la quinta ronda. Washington: 2015. Disponível em http://www.oas.org/es/sla/dlc/mesicic/docs/mesicic5_metodologia_sp.pdf. Acesso em 11.12.2018.

OEA. Plano de ação aprovado na Primeira Reunião de Cúpula das Américas. Dezembro de 1994. Disponível em http://www.summit-americas.org/i_summit_sp.html. Acesso em 28.11.2018.

OEA. Relatório hemisférico da primeira rodada de análise da Comissão de Peritos do MESICIC. Washington: 2006.

OEA. Relatório referente à implementação na República Federativa do Brasil das disposições da Convenção selecionadas para serem analisadas na terceira rodada e sobre o acompanhamento das recomendações formuladas ao país nas rodadas anteriores. Washington: 2011. Disponível em http://www.oas.org/juridico/PDFs/mesicic3 bra por.pdf. Acesso em 11.12.2018.

OEA. Resolução AG/RES 1294 (XXIV-O/94). Aprovada pela Assembleia Geral em 10 de junho de 1994. Disponível em http://www.oas.org/es/council/AG/ResDec/. Acesso em 20.11.2018.

OEA. Resolução AG/RES 1346 (XXV-O/95). Aprovada pela Assembleia Geral em 09 de junho de 1995. Disponível em http://www.oas.org/es/council/AG/ResDec/. Acesso em 20.11.2018.

OECD. Fase III- Relatório sobre a implementação da Convenção sobre o Combate da Corrupção de Funcionários Públicos Estrangeiros em Transações Comerciais Internacionais no Brasil. Paris: 2014. Disponível em http://www.cgu.gov.br/assuntos/articulacao-internacional/convencao-daocde/arquivos/avaliacao3_portugues.pdf. Acesso em 03.12.2018. 
OECD. Phase 3 report on implementing the OECD Anti-Bribery Convention in the United Kingdom. Paris: 2012. Disponível em https://www.oecd.org/daf/antibribery/UnitedKingdomphase3reportEN.pdf. Acesso em 05.04.1019.

OECD. Phase 3 report on implemeting the OECD Convention in France. Paris: 2012. Disponível em http://www.oecd.org/daf/anti-bribery/Francephase3reportEN.pdf, P. 71.; OECD. France: follow-up to the phase 3 report \& recomendations. Paris: 2014. Disponível em http://www.oecd.org/daf/anti-bribery/France-Phase-3-Written-Follow-up-ENG.pdf. Acesso em 06.04.2019.

OECD. Recomendação do Conselho para Melhoria da Conduta Ética na Função Pública. Disponível em https://legalinstruments.oecd.org/en/instruments/OECD-LEGAL-0298. Acesso em 12.12.2018.

OECD. Recomendação do DAC sobre Propostas de Combate à Corrupção em Contratações Financiadas por Terceiros. Disponível em https://legalinstruments.oecd.org/en/instruments/OECD-LEGAL-5013. Acesso em 12.12.2018.

OECD. Recomendação sobre a corrupção em transações comerciais internacionais. Disponível em https://legalinstruments.oecd.org/en/instruments/OECD-LEGAL-0276. Acesso em 12.12.2018.

OECD. Recomendação sobre Dedução Fiscal de Propinas pagas a Funcionários Públicos Estrangeiros. Disponível em https://legalinstruments.oecd.org/en/instruments/OECDLEGAL-0286. Acesso em 12.12.2018.

OECD. Relatório sobre a aplicação da Convenção sobre o Combate ao Suborno de Funcionários Público Estrangeiros em Transações Internacionais e a Recomendação revisada de 1997 sobre o combate ao suborno em transações comerciais internacionais. Brasil: Fase 2. Paris: 2009. Disponível em http://www.cgu.gov.br/assuntos/articulacaointernacional/convencao-da-ocde/arquivos/avaliacao2_portugues.pdf. Acesso em 11.12.2018.

OECD. Revisão da implementação da Convenção e da Recomendação de 1997. Brasil: Fase 1. Paris: 2004. Disponível em http://www.cgu.gov.br/assuntos/articulacaointernacional/convencao-da-ocde/arquivos/avaliacao1_portugues.pdf. Acesso em 02.12.2018.

OLIVARES, Gonzalo Quintero. La autotutela, los limites al poder sancionador de la administración publica y los princípios inspiradores del derecho penal. Revista de Administración Pública. N. 126. 1991. P. 253, 293. 
OLIVEIRA, Ana Carolina Carlos de. Direito de intervenção e direito administrativo sancionador: o pensamento de Hassamer e o direito penal brasileiro. 2012. Dissertação (Mestrado em Direito Penal) - Faculdade de Direito, Universidade de São Paulo, São Paulo.

OLIVEIRA, Ary Brandão de. A responsabilidade civil das pessoas jurídicas de direito privado por atos ilícitos. Doutrinas Essenciais de Responsabilidade Civil. Vol. 3. São Paulo: Revista dos Tribunais, 2011. Versão obtida digitalmente. P. 73, 105.

OLIVEIRA, Edmundo. Crimes de corrupção. Rio de Janeiro: Forense, 1994.

OLIVEIRA, Gustavo Henrique Justino de; ACCIOLI FILHO, Wilson. A Estratégia Nacional de Combate à Corrupção e à Lavagem de Dinheiro (ENCCLA) como experiência cooperativa interinstitucional de governo aberto no Brasil. In CUNHA FILHO, Alexandre Jorge Carneiro da (coord.). 48 visões sobre a corrupção. São Paulo: Quartier Latin, 2016. P. 305,335 .

OLIVEIRA, Gustavo Henrique Justino de; SCHIEFLER, Gustavo Henrique Carvalho. Operações de fusão e aquisição e as intercorrências a partir dos acordos de leniência. in CARVALHO, André Castro, et alli (Coord.). Manual de Compliance. Rio de Janeiro: Forense, 2019. P. 421, 441,

OLIVEIRA, Gustavo Henrique Justino de; SOUZA, Otavio Augusto Venturini de. Controladoria-Geral da União: uma Agência Anticorrupção? In PEREZ, Marcos Augusto; SOUZA, Rodrigo Pagani de. Controle da Administração Pública. Belo Horizonte: Fórum, 2017. P. 323, 334.

OLIVEIRA, Gustavo Justino de; SCHIEFLER, Gustavo Henrique Carvalho. Justa causa e juízo de prelibação (admissibilidade) na ação de improbidade administrativa: proteção e preservação dos direitos e garantias dos requeridos frente à busca de maior eficiência judicial no combate à corrupção na era da Operação Lava Jato. Revista Síntese Direito Administrativo. Ano 12, n 141. São Paulo: Síntese, 2017. P. 311, 326.

OLIVEIRA, José Roberto Pimenta de. Improbidade administrativa e sua autonomia constitucional. Belo Horizonte: Fórum, 2009.

OLIVEIRA, José Roberto Pimenta. Comentários ao art. 2. In DI PIETRO, Maria Sylvia Zanella; MARRARA, Thiago. Lei Anticorrupção comentada. Belo Horizonte: Fórum, 2017. P. 23, 46.

OLIVEIRA, Luciano Moreira. Crimes contra a administração pública e improbidade administrativa: medidas de prevenção e repressão. Revista dos Tribunais. V. 9/2014. São Paulo, 2014. P. 255, 273. 
OLIVEIRA, Mariana Matos de Oliveira. Medida provisória sobre acordo de leniência aprimora a Lei Anticorrupção. Revista Eletrônica Consultor Jurídico. Publicado em 17 de janeiro de 2016.

OLIVEIRA, Rafael Carvalho Rezende. NEVES, Daniel Amorim Assumpção. O sistema brasileiro de combate à corrupção e a Lei n ${ }^{\circ}$ 12.846/2013 (lei anticorrupção). RBDP. V. 44. Belo Horizonte: Fórum, 2014. Versão obtida digitalmente. P. 9, 21.

OLIVEIRA, Régis Fernandes. Infrações e sanções administrativas. $3^{\text {a }}$ Ed. São Paulo: RT, 2012.

ONU. Resolução 55/25, aprovada pela Assembleia Geral em 15 de novembro de 2000. Disponível em https://undocs.org/es/A/RES/55/25. Acesso em 15.12.2018.

ONU. Resolução 55/61, aprovada pela Assembleia Geral da ONU em 04 de dezembro de 2000. Disponível em https://undocs.org/es/A/RES/55/61. Acesso em 15.12.2018.

ONU. Resolução 58/4, aprovada pela Assembleia Geral da ONU em 31 de outubro de 2003.

ORTOLAN, Marcelo. A responsabilidade objetiva da pessoa jurídica pela prática de atos de corrupção: norma penal ou administrativa. Revista Justiça e Sistema Criminal. Vol. 8, n. 14, jan/jun 2016. P. 151, 166.

OSÓRIO, Fábio Medina. 21 respostas sobre Lei Anticorrupção e Lava Jato. Portal JOTA. Publicado em 19.032015.

OSÓRIO, Fábio Medina. Autocontrole previne danos a empresa. Opinião. Jornal O Tempo. Belo Horizonte. Publicado em 23.07.2019.

OSÓRIO, Fábio Medina. Corrupcion y mala gestion de la res publica: el problema de la improbidad administrativa y su tratamiento en el derecho administrativo sancionador brasileño. Revista de Administración Pública. N. 149, Mayo-Agosto 1999. P. 487,522.

OSÓRIO, Fábio Medina. Direito administrativo sancionador. $5^{\text {a }}$ Ed. São Paulo: RT, 2015.

OSÓRIO, Fábio Medina. Judiciário pode anular acordo de leniência com empreiteiras. Revista Carta Capital. Publicado em 23.02.2015.

OSÓRIO, Fábio Medina. Lei anticorrupção dá margem a conceitos perigosos. Revista Consultor Jurídico. 20.09.2013. Disponível em https://www.conjur.com.br/2013-set-20/leianticorrupcao-observar-regime-direito-administrativo-sancionador. Acesso em 01.02.2018. 
OSÓRIO, Fábio Medina. Natureza jurídica de improbidade administrativa. Revista de Direito da Procuradoria Geral: Administração Pública, Risco e Segurança Jurídica. Rio de Janeiro, 2014. P. 455, 460.

OSÓRIO, Fábio Medina. Teoria da improbidade administrativa. - Má gestão pública, Corrupção e Ineficiência. $3^{\mathrm{a}}$ Ed. São Paulo: Editora Revista dos Tribunais, 2013.

PAGLIARO, Antonio; COSTA JUNIOR, Paulo José da. Dos crimes contra a administração pública. 3 Ed. São Paulo: Perfil, 2006.

PAGOTTO, Leopoldo. Esforços globais anticorrupção e seus reflexos no Brasil. In DEL DEBBIO, Alessandra; MAEDA, Bruno Carneiro; AYRES, Carlos Henrique da Silva. Temas de anticorrupção \& compliance. São Paulo: Campus Jurídico, 2013. P. 21, 44.

PASCHOAL, Janaína Conceição. Constituição, criminalização e direito penal mínimo. São Paulo: RT, 2003.

PEREIRA, Caio Mário da Silva. Responsabilidade Civil. $2^{\mathrm{a}}$ Ed. Forense: Rio de Janeiro, 1991.

PEREIRA, Cesar Guimarães; SCHWIND, Rafael Wallbach. Autossaneamento (selfcleaning) e reabilitação no direito anticorrupção. Revista de direito administrativo contemporâneo-REDAC. V. 20. 2015. P. 13, 34.

PEREZ Jesús Gonzalez. Administración Pública y moral. Civitas Ediciones (Thomson Reuters), 2016.

PEREZ, Jesús Gonzalez. Corrupción, ética y moral in las administraciones publicas. $2^{\mathrm{a}}$ Ed. Civitas Ediciones (Thomson Reuters), 2014.

PEREZ, Jesús Gonzalez. La ética en la Administración Pública. $2^{\mathrm{a}}$ Ed. Civitas Ediciones (Thomson Reuters), 2000.

PETRELlUZZI, Marco Vinício; RIZEK JUNIOR, Rubens Naman. Lei anticorrupção. Origens, comentários e análise da legislação correlata. São Paulo: Saraiva, 2014.

PIERANGELLI, José Henrique. A culpabilidade e o novo sistema penal. Doutrinas Essenciais de Direito Penal. Vol. 3. São Paulo: Revista dos Tribunais, 2010. Versão obtida digitalmente. P. 683, 692. 
PIMENTEL FILHO, André. Comentários aos artigos $1^{\circ}$ a $4^{\circ}$ da Lei Anticorrupção. In SOUZA, Jorge Munhós de; QUEIROZ, Ronaldo Pinheiro de. Lei Anticorrupção. Salvador: JusPODIVM, 2015. P. 63, 88.

PIMENTEL, Rafael Niepce Verona. A evolução da responsabilidade sob os pontos de vista jurídico e filosófico. Revista Annales. V. 2. N. 2. Belo Horizonte: 2017.

PIOVESAN, Flávia. Direitos humanos e o direito constitucional internacional. São Paulo: Saraiva, 2011.

PIRONTI, Rodrigo. MP 703/15 reafirma independência dos controles internos. Revista Eletrônica Consultor Jurídico. Publicado em 10.01.2016.

PNUD. Programas Anticorrupción en América Latina y el Caribe. Estudios sobre tendencias anticorrupción $y$ proyetos del PNUD. Disponível em https://www.researchgate.net/publication/216370449_Programas_anticorrupcion_en_Amer ica_Latina_y_el_Caribe_Estudio_sobre_tendencias_anticorrupcion_y_programas_del_PN UD. 2011. Acesso em 31.05.2019.

PONTES DE MIRANDA, Francisco. Comentários ao Código de Processo Civil. Versão digital: 2006.

PORTELA, Paulo Henrique Gonçalves. Direito internacional público e privado. $3^{\mathrm{a}}$ Ed. Salvador: JusPodium, 2011.

PORTO, Mário Moacyr. O ocaso da culpa como fundamento da responsabilidade civil. Doutrinas Essenciais de Responsabilidade Civil. Vol. 1. São Paulo: Revista dos Tribunais, 2011. Versão obtida digitalmente. P. 499, 506.

PRADO, Luís Regis. Norma penal como norma de conduta. Doutrinas Essenciais de Direito Penal Econômico e da Empresa. Vol. 1. São Paulo: Revista dos Tribunais, 2011. Versão obtida digitalmente. P. 227, 287.

PRADO, Luiz Regis. Bem jurídico-penal e constituição. 7ª Ed. São Paulo: RT, 2014.

PRADO, Luiz Regis. Comentários ao código penal. 6ª Ed. São Paulo: RT, 2011.

PRADO, Luiz Régis. Crimes contra o ambiente. São Paulo: RT 1998.

PRADO, Luiz Regis. DOTTI, René Ariel. Responsabilidade penal da pessoa jurídica. Em defesa do princípio da imputação penal subjetiva. 4a Ed. São Paulo: RT, 2013. 
PRADO, Luiz Régis. Teoria dos fins da pena: breves reflexões. Revista de Ciências Penais. V. 0. Jan/2004. Versão obtida digitalmente.

PÜSCHEL, Flavia Portella. Funções e princípios justificadores da responsabilidade civil e o art. 927, § único do Código Civil. Revista Direito GV. v. 1, n. 1, p. 91-107, mai. 2005. Disponível em: http://bibliotecadigital.fgv.br/ojs/index.php/revdireitogv/article/view/35266. Acesso em: 26.05.2018.

QUEIROZ, Rafel Mafei Rabelo. Responsabilidade penal das pessoas jurídicas. Doutrinas Essenciais de Direito Penal Econômico e da Empresa. Vol. 1. São Paulo: Revista dos Tribunais, 2011. Versão obtida digitalmente. P. 1069, 1092.

QUEIROZ, Ronaldo Pinheiro de. SOUZA, Jorge Munhos (org.). Lei Anticorrupção. Editora Juspodium, 2015.

RAMINA, Larissa O.. Tratamento jurídico internacional da Corrupção: a convenção interamericana contra a corrupção da OEA e a convenção sobre o combate da corrupção de funcionários estrangeiros em transações comerciais internacionais da OCDE. Revista da Faculdade de Direito da UFPR, v. 39. 2003. P. 202, 213.

REALE JÚNIOR, Miguel. Despenalização no direito penal econômico: uma terceira via entre o crime e a infração administrativa? Doutrinas Essenciais de Direito Penal Econômico e da Empresa. Vol. 1. São Paulo: Revista dos Tribunais, 2011. Versão obtida digitalmente. P. 647, 665.

REALE, Miguel. Filosofia do Direito. 20ª Ed. $3^{\text {a }}$ Tir. São Paulo: Saraiva, 2002.

REALE, Miguel. Lições preliminares de Direito. 27ª Ed. 9a Tir. São Paulo: Saraiva, 2009.

REALE, Miguel. Novos aspectos da responsabilidade civil e penal. In REALE, Miguel. Temas de Direito Positivo. São Paulo: RT, 1992. P. 54, 75.

REALE, Miguel. O Estado Democrático de Direito e o conflito de ideologias. $3^{\text {a }}$ Ed. $2^{\text {a }}$ Tir. São Paulo: Saraiva, 2010.

REGULES, Luís Eduardo Patrone. A lei anticorrupção e o terceiro setor. Revista dos Tribunais. V. 947/2014. São Paulo: Editora Revista dos Tribunais. Versão obtida digitalmente. P. 237.

REINO DA ESPANHA. Lei Orgânica $n^{o}$ 5, de 22.06.2010. Disponível em https://www.boe.es/eli/es/lo/2010/06/22/5. Acesso em 06.04.2019. 
REPÚBLICA ARGENTINA. Lei $n^{o}$ 27.401, de 01.12.2017. Disponível em https://www.argentina.gob.ar/normativa/nacional/ley-27401-296846/texto. Acesso em 06.04.2019.

REPÚBLICA ARGENTINA. Ministério de Justiça y Derechos Humanos. Lineamientos de Integridad para el mejor cumplimiento de lo establecido en los artículos 22 y 23 de Ley $n^{o}$ 27.401 de responsabilidade penal de las personas jurídicas. 2018. Disponível em https://www.boletinoficial.gob.ar/\#!DetalleNorma/193241/20181004.

REPÚBLICA DA COLÔMBIA. Lei $n^{o}$ 1.778, de 02.02.2016. Disponível em http://es.presidencia.gov.co/normativa/normativa/LEY\%201778\%20DEL\%2002\%20DE\% 20FEBRERO\%20DE\%202016.pdf. Acesso em 06.04.2019.

REPÚBLICA DA COLÔMBIA. Supersociedades. Circular Externa $n^{o}$ 100-000003. Disponível em https://www.supersociedades.gov.co/nuestra entidad/normatividad/normatividad circulare s/Circular\%20Externa\%20100-000003\%2026-07-16.pdf. Acesso em 06.04.2019.

REPÚBLICA DO CHILE. Lei $n^{o}$ 20.393, de 02.12.2009. Disponível em https://www.leychile.cl/Navegar?idNorma=1008668. Acesso em 06.04.2019.

REPÚBLICA DO PERU. Lei $n^{o}$ 30.424, de 20.04.2016. Disponível em https://www.legiscompliance.com.br/legislacao/norma/161. Acesso em 06.04.2019.

REPUBLIQUE FRANÇAISE. Agence Francaise Anticorruption. Charte des droits et devoirs des parties prenantes aux controles. Paris, 2019. Disponível em https://www.agence-francaise-

anticorruption.gouv.fr/files/files/charte droits devoirs unique\%20controles.pdf.

REPUBLIQUE FRANÇAISE. Agence Française Anticorruption. Guide pratique La fonction conformité anticorruption dans l'entreprise. 2019. Disponível em https://www.economie.gouv.fr/files/files/directions_services/afa/2019-01-29_-

Guide pratique fonction conformite.pdf. Acesso em 02.04.2019.

REPUBLIQUE FRANÇAISE. Agence Francaise Anticorruption. Les contrôles de l'AFA. Disponível em https://www.agence-francaise-anticorruption.gouv.fr/fr/controles-lafa.

REPUBLIQUE FRANÇAISE. Étude d'impact. Projet de loi relatif à la transparence, à la lutte contre la corruption et à la modernisation de la vie économique. 2016. Disponível em https://www.legifrance.gouv.fr/affichLoiPubliee.do?idDocument=JORFDOLE0000323197 92\&type=general\&1. Acesso em 06.04.2019. 
REPUBLIQUE FRANÇAISE. Lei $n^{o}$ 1.691, de 01.06.2017. Disponível em Disponível em https://www.legifrance.gouv.fr/affichTexte.do?cidTexte=JORFTEXT000033558528\&date Texte $=20171003$. Acesso em 06.04.2019.

RIBAS JUNIOR, Salomão. Corrupção, pública e privada - Quatro aspectos. Belo Horizonte: Fórum, 2014.

RIBAS, Lídia Maria Lopes Rodrigues. Responsabilidade penal da pessoa jurídica. Doutrinas Essenciais de Direito Penal Econômico e da Empresa. Vol. 3. São Paulo: Revista dos Tribunais, 2011. Versão obtida digitalmente. P. 1035, 1050.

RIBEIRO, Lúcio Ronaldo Pereira. Da responsabilidade penal da pessoa jurídica e a nova lei dos crimes ambientais. Doutrinas Essenciais de Responsabilidade Civil. Vol. 7. São Paulo: Revista dos Tribunais, 2011. Versão obtida digitalmente. P. 359, 372.

RIBEIRO, Maria Clara Pereira. DINIZ, Patrícia Dittrich Ferreira. Compliance e Lei Anticorrupção nas empresas. Revista de Informação Legislativa. N. 205. Brasília: 2015. P. $87,105$.

RICO, Bruno Gabriel de Melo. O papel da controladoria-geral da união no sistema de integridade brasileiro. 2014. Mestrado em Ciência Sociais. Pontifícia Universidade Católica de São Paulo - PUC/SP, São Paulo.

RINCÓN, José Suay. El derecho administrativo sancionador: perspectivas de reforma. Revista de Administración Pública. N. 109. 1986. P. 185, 215.

ROCHA, Carmem Lúcia Antunes. Princípios constitucionais da Administração Pública. $1^{\mathrm{a}}$ Ed. Belo Horizonte: Del Rey, 1994.

ROCHA, Cármen Lúcia Antunes. Princípios Constitucionais da Administração Pública. Belo Horizonte: Del Rey, 1994.

ROCHA, Cármen Lúcia Antunes. República e federação no Brasil. Belo Horizonte: Del Rey, 1997.

ROCHA, Fernando Antonio N. Galvão da. A culpabilidade como fundamento da responsabilidade penal. Doutrinas Essenciais de Direito Penal. Vol. 3. São Paulo: Revista dos Tribunais, 2010. Versão obtida digitalmente. P. 387, 408.

ROCHA, Fernando Antonio N. Galvão da. Conteúdo material da culpabilidade. Revista de Ciências Penais. Vol. 15/2011. São Paulo: Revista dos Tribunais, 2011. Versão obtida digitalmente. P. 133, 171. 
ROCHA, Sílvio Luís Ferreira da. Responsabilidade objetiva da pessoa jurídica na Lei $\mathrm{n}^{\circ}$ 12.846, de $1^{\circ}$ de agosto de 2013. Revista Brasileira de Infraestrutura. N. 7. Belo Horizonte, 2015. P. 131, 142.

ROSA, Márcio Fernando Elias. JUNIOR, Wallace Paiva Martins. Estudo comparativo entre as leis 8.429/1992 e 12.846/2013. Revista dos Tribunais. V. 947/2014. São Paulo: Editora Revista dos Tribunais. Versão obtida digitalmente.

ROSE-ACKERMAN, Susan. CARRINGTON, Paul. Anti-corruption policy. Durham: Carolina Academic Press, 2013.

ROSE-ACKERMAN, Susan. Corruption and Government. Causes, consequences, and reform. Cambridge: Cambridge University Press, 1999.

ROSE-ACKERMAN, Susan. Corruption: a study in political economy. New York: Academic Press, 1978. Versão digital disponível em http://www.ie.ufrj.br/intranet/ie/userintranet/hpp/arquivos/251120153307_SusanRoseAcke rmanCorruption.AStudyinPoliticalEconomy.pdf. Acesso em 03.11.2018.

ROSE-ACKERMAN, Susan. International handbook on the economics of corruption. Northampton: Edgard Elgar Publishing, 2006.

ROSILHO, André. Poder regulamentar do TCU e o Acordo de leniência na Lei Anticorrupção. Colunistas. Portal "Direito do Estado". Publicado em 07.04.2016.

ROSSI, Helena Costa. Intervenção jurídico-penal na sociedade globalizada: aspectos da responsabilidade penal da pessoa jurídica. Revista Brasileira de Ciências Criminais. Vol. 140/2018. São Paulo: Revista dos Tribunais, 2018. Versão obtida digitalmente. P. 71, 107.

ROTHENBURG, Walter Claudius. A pessoa jurídica criminosa. Curitiba: Juruá, 1997.

ROXIN, Claus. A culpabilidade e sua exclusão no Direito Penal. Doutrinas Essenciais de Direito Penal. Vol. 3. São Paulo: Revista dos Tribunais, 2010. Versão obtida digitalmente. P. 191, 213.

RUBIO, María Gracia. Postetad sancionatoria de la administración y garantias del administrado: comentário a la sentencia del Tribunal Europeo de Derechos Humanos de 21 de Febrero de 1984: el caso Oztürk. Revista de Administración Pública - RAP. N. 104. Madrid, 1984. P. 375, 390.

SAAD-DINIZ, Eduardo. Ética negocial e compliance. São Paulo: RT, 2019. 
SALVADOR NETTO, Alamiro Velludo. Breves anotações sobre os crimes de corrupção passiva e corrupção privada na legislação penal espanhola. In PASCHOAL, Janaína Conceição; SILVEIRA, Renato Mello de Jorge (org.). Livro homenagem a Miguel Reale Júnior. Rio de Janeiro: LMJ Mundo Jurídico, 2014. P. 1, 16.

SALVADOR NETTO, Alamiro Velludo. Responsabilidade penal da pessoa jurídica. São Paulo: RT, 2018.

SAMPAIO, Gabriel de Carvalho. VAZZOLER, Anna Claudia Pardini. Lei anticorrupção e a abrangência do inciso V do art. 5. Revista dos Tribunais. V. 947/2014. São Paulo: Editora Revista dos Tribunais. Versão obtida digitalmente.

SANTOS, José Anacleto Abduch. Comentários à lei 12.846. São Paulo: Editora Revista dos Tribunais, 2014.

SANTOS, Kleber Bispo dos. Improbidade Administrativa e Atentado aos Princípios da Administração Pública. Belo Horizonte: Fórum, 2011.

SARCEDO, Leandro. Compliance e responsabilidade penal da pessoa jurídica: construção de um novo modelo de imputação, baseada na culpabilidade corporativa. 2014. Tese (Doutorado em Direito Penal). Faculdade de Direito - Universidade de São Paulo, São Paulo.

SCLEIFER, Andrei; VISHNY, Robert W. Corruption. The Quartely Journal of Economics, vol. 108, n. 3, ago. 1993. P. 599, 617. Disponível em https://projects.iq.harvard.edu/gov2126/files/shleifer and vishy.pdf. Acesso em 04.12.2018.

SERRANO, Hermes Wagner Betete Sampaio. PAZETO, Henrique Parisi. A ação de improbidade administrativa como tutela da moralidade administrativa. Revista Fórum Administrativo. N. 165. Belo Horizonte, 2014. P. 45, 52.

SILVA, Clóvis do Couto e. O princípio da boa-fé no Direito brasileiro e português. In FRADERA, Vera Maria Jacob de (org.). O Direito privado brasileiro na visão de Clóvis do Couto e Silva. Porto Alegre: Livraria do Advogado, 1997. P. 33, 58.

SILVA, Davi Castro. Bem jurídico penal: algumas compreensões, breves reflexões. Doutrinas Essenciais de Direito Penal Econômico e da Empresa. Vol. 1. São Paulo: Revista dos Tribunais, 2011. Versão obtida digitalmente. P. 1209, 1227.

SILVA, De Plácido e. Vocabulário jurídico conciso. atual. por Nagib Slaibi Filho e Gláucia Carvalho. $2^{\text {a }}$ Ed. Rio de Janeiro: Forense, 2010. 
SILVA, Fernando Quadro da. Responsabilidade penal da pessoa jurídica: a Lei 9.605 de13.02.1998 e os princípios constitucionais penais. Doutrinas Essenciais de Direito Penal Econômico e da Empresa. Vol. 3. São Paulo: Revista dos Tribunais, 2011. Versão obtida digitalmente. P. 249, 290.

SILVA, Franklin Leopoldo e. A ética necessária: responsabilidade e solidariedade. Café Filosófico CPFL (Parceria entre a TV Cultura e o Instituto CPFL). São Paulo: TV Cultura, 2018. Duração 50'10". Disponível em https://www.youtube.com/watch?v=dFRMFAgBLpQ\&t=1526s. Acesso em 22.05.2018.

SILVA, Ivan Luís Marques da. Direito penal neo-constitucionalista. Doutrinas essenciais de Direito Constitucional. V. 7. São Paulo: RT, 2015. P. 205, 224.

SILVA, Ivan Luís Marques da. Responsabilidade penal das pessoas jurídicas: 21 anos da previsão constitucional e 11 anos da previsão legal: um balanço necessário. Doutrinas Essenciais de Direito Penal Econômico e da Empresa. Vol. 1. São Paulo: Revista dos Tribunais, 2011. Versão obtida digitalmente. P. 989, 1024.

SILVA, Jorge Alberto Quadros de Carvalho. Responsabilidade objetiva: o código civil de 2002 e o código de defesa do consumidor. Doutrinas Essenciais de Responsabilidade Civil. Vol. 4. São Paulo: Revista dos Tribunais, 2011. Versão obtida digitalmente. P. 425, 436.

SILVA, Wilson de Mello. Responsabilidade sem culpa e socialização do risco. Belo Horizonte: Bernardo Álvares, 1962.

SILVEIRA, Luciana Dutra de. A nova geração de leis anticorrupção: os possíveis impactos da Lei da Empresa Limpa para o comércio internacional brasileiro. 2018. Tese (Doutorado em Direito). Faculdade de Direito - Pontifícia Universidade Católica de São Paulo, São Paulo.

SILVEIRA, Renato de Mello Jorge. O acordo de leniência na lei anticorrupção. Revista dos Tribunais. V. 947/2014. São Paulo: Editora Revista dos Tribunais. Versão obtida digitalmente. P. 157.

SILVEIRA, Renato de Mello Jorge; SAAD-DINIZ, Eduardo. Compliance, direito penal e lei anticorrupção. $2^{\mathrm{a}}$ tir. São Paulo: Saraiva, 2017.

SIRVINSKAS, Luís Paulo. Responsabilidade penal da pessoa jurídica na Lei 9.605/98. Doutrinas Essenciais de Direito Penal Econômico e da Empresa. Vol. 1. São Paulo: Revista dos Tribunais, 2011. Versão obtida digitalmente. P. 1051, 1068. 
SOARES, Vivian. ROSA, Maria Alice. Nova cultura. Jornal Valor Econômico. Publicado em 11 de maio de 2015.

SOBRINHO, Jorge Hage. Lei 12.846/2013: lei da empresa limpa. Revista dos Tribunais. V. 947/2014. São Paulo: Editora Revista dos Tribunais. Versão obtida digitalmente.

SOUZA, Patrícia Verônica Nunes de Carvalho Sobral. Corrupção e Improbidade. Críticas e controle. Belo Horizonte: Fórum, 2012.

SOUZA, Ricardo Inglez. SILVEIRA, Luciana Dutra de Oliveira. Lei anticorrupção e a defesa da concorrência. Revista dos Tribunais. V. 947/2014. São Paulo: Editora Revista dos Tribunais. Versão obtida digitalmente. P. 201,211.

SPERCEL, Thiago. Considerações sobre a responsabilidade solidária do grupo econômico por atos de corrupção. Revista dos Tribunais. V. 947/2014. São Paulo: Editora Revista dos Tribunais. Versão obtida digitalmente. P. 281.

SPOSATO, Karyna Batista. Culpa e castigo: modernas teorias da culpabilidade e os limites ao poder de punir. Doutrinas Essenciais de Direito Penal. Vol. 3. São Paulo: Revista dos Tribunais, 2010. Versão obtida digitalmente. P. 745, 767.

STOCO, Rui. A teoria do resultado à luz do código de defesa do consumidor. Doutrinas Essenciais de Responsabilidade Civil. Vol. 4. São Paulo: Revista dos Tribunais, 2011. Versão obtida digitalmente. P. 539, 567.

SUNSTEIN, Cass, R.; VERMEULE, Adrian. The morality of administrative law. Harvard Law Review. V. 131. No 07. Maio de 2018. P. 1924, 1978. P. 1925 Disponível em https://harvardlawreview.org/wp-content/uploads/2018/05/1924-1978 Online.pdf. Acesso em 20.06.2019.

TÁCITO, Caio. Improbidade como forma de corrupção. In Revista de Direito Administrativo - RDA, V. 226. Rio de Janeiro: Renovar, 2001. P. 1, 3.

TAMASAUSKAS, Igor Sant'Anna. A corrupção política: hipótese de sobrecarga dos instrumentos jurídicos de responsabilização por atos de corrupção no Brasil. 2017. Dissertação (Mestrado em Direito) - Faculdade de Direito, Universidade de São Paulo, São Paulo.

TAMASAUSKAS, Igor Sant'anna; BOTTINI, Pierpaolo Cruz. A interpretação constitucional possível da responsabilidade objetiva na Lei Anticorrupção. Revista dos Tribunais. V. 947/2014. São Paulo: Revista dos Tribunais, 2014. Versão obtida digitalmente. 
TANGERINO, Davi de Paiva Costa. Culpabilidade e responsabilidade penal da pessoa jurídica. Doutrinas Essenciais de Direito Penal Econômico e da Empresa. Vol. 1. São Paulo: Revista dos Tribunais, 2011. Versão obtida digitalmente. P. 877, 900.

TEIXEIRA, Ana Bárbara Costa. A empresa-instituição. 2010. Dissertação (Mestrado em Direito) - Faculdade de Direito. Universidade de São Paulo, São Paulo.

TIEDEMANN, Klaus. Punibilidad y Responsabilidad Administrativa de las Personas Jurídicas y de sus Órganos. Revista Jurídica de Buenos Aires. Buenos Aires: Facultad de Derecho y Ciencias Sociales de la Universidad de Buenos Aires, vol. 2, p. 11 e ss., 1988.

TIEDEMANN, Klaus. Responsabilidad penal de personas jurídicas y empresas en derecho comparado. Doutrinas Essenciais de Direito Penal. Vol. 3. São Paulo: Revista dos Tribunais, 2010. Versão obtida digitalmente. P. 787, 805.

TIMM, Luciano Benetii. Os grandes modelos de responsabilidade civil no direito privado: da culpa ao risco. Doutrinas Essenciais de Responsabilidade Civil. Vol. 1. São Paulo: Revista dos Tribunais, 2011. Versão obtida digitalmente. P. 289, 310.

TOJAL, Sebastião. Interpretação do artigo 30 da lei 12.846/2013. Revista dos Tribunais. V. 947/2014. São Paulo: Editora Revista dos Tribunais. Versão obtida digitalmente. P. 281.

TRANSPARENCY INTERNATIONAL. Business principles for countering bribery. 2013.

TREBILCOCK, Michael J.; PRADO, Mariana Mota. What makes poor countries poor. Edward Elgar Press, 2011.

UNITED KINGDOM. Bribery Act 2010: Joint Prosecution Guidance of The Director of the Serious Fraud Office and The Director of Public Prosecutions. Disponível em https://www.cps.gov.uk/legal-guidance/bribery-act-2010-joint-prosecution-guidancedirector-serious-fraud-office-and\#a19. Acesso em 05.04.2019.

UNITED KINGDOM. Ministry of Justice. The Bribery Act 2010 - Guidance. Disponível em

https://assets.publishing.service.gov.uk/government/uploads/system/uploads/attachment_d ata/file/181762/bribery-act-2010-guidance.pdf. Acesso em 05.04.2019.

UNITED KINGDOM. The Bribery Act 2010 - Quick Start Guide. Disponível em https://assets.publishing.service.gov.uk/government/uploads/system/uploads/attachment_d ata/file/181764/bribery-act-2010-quick-start-guide.pdf. Acesso em 02.04.2019. 
UNITED KINGDOM. United Kingdon Bribery Act, de 08.04.2010. Disponível em http://www.legislation.gov.uk/ukpga/2010/23/pdfs/ukpga 20100023 en.pdf. Acesso em 04.04.2019.

UNITED STATES OF AMERICA. 2001 Report of Investigation Pursuant to Section 21(a) of the Securities Exchange Act of 1934 and Commission Statement on the Relationship of Cooperation to Agency enforcement decisions. Disponível em https://www.sec.gov/litigation/investreport/34-44969.htm. Acesso em 03.04.2019.

UNITED STATES OF AMERICA. Criminal Division of the US Department of Justice; Enforcement Division of the US Securities and Exchange Comission. A Resource Guide to the US Foreign Corrupt Practices Act. Disponível em https://www.sec.gov/spotlight/fcpa/fcpa-resource-guide.pdf. Acesso em 03.04.2019.

UNITED STATES OF AMERICA. Criminal Division of U.S. Department of Justice; Enforcement Division of the U.S. Securities and Exchange Commission. FCPA. A resource guide to the U. S. Foreign Corrupt Practices Act.

UNITED STATES OF AMERICA. Department of Justice. Former Morgan Stanley Managing Director Pleads Guilty for Role in Evading Internal Controls Required by FCPA. 25.04.2012. Disponível em https://www.justice.gov/opa/pr/former-morgan-stanleymanaging-director-pleads-guilty-role-evading-internal-controls-required. Acesso em 03.04.2019.

UNITED STATES OF AMERICA. DOJ. Fraud Section Evaluation of Corporate Compliance Programs. Disponível em em https://www.justice.gov/criminalfraud/page/file/937501/download.

UNITED STATES OF AMERICA. Principles of Federal Prosecution of Business Organizations. Disponível em https://www.justice.gov/jm/jm-9-28000-principles-federalprosecution-business-organizations. Acesso em 03.04.2019.

UNITED STATES OF AMERICA. U. S. Sentencing Guidelines. Disponível em https://www.ussc.gov/guidelines/2015-guidelines-manual/2015-chapter-8. Acesso em 03.04.2019.

UNODC. $\quad$ CAC/COSP. Resolução $3 / 1 . \quad$ Disponível em http://www.unodc.org/documents/treaties/UNCAC/COSP/session3/V0988538e.pdf. Acesso 11.12.2018.

UNODC. Country Review Report of Brazil. Disponível em http://www.unodc.org/documents/treaties/UNCAC/CountryVisitFinalReports/2017 0119 _Brazil_Final_Country_Report.pdf. Acesso em 11.12.2018. 
US CHAMBER OF COMMERCE. Business community responds to FCPA enforcement guidance by DOJ and SEC. 18.02.2013. Disponível em https://www.uschamber.com/pressrelease/business-community-responds-fcpa-enforcement-guidance-doj-and-sec. Acesso em 04.04.2019.

VALE, Murilo Melo. A Lei anticorrupção empresarial: um contraponto à agenda de combate à corrupção. Revista Brasileira de Estudos da Função Pública - RBFEP. N. 11. Belo Horizonte, 2015. P. 191, 214.

VÁQUEZ, J. Ramón Parada. El poder sancionador de la administración y la crisis del sistema judicial penal. Revista de Administración Pública. N. 67. 1972. P. 41, 93.

VASCONCELLOS, Paulo. Aplicação da lei anticorrupção é incipiente. Jornal Valor Econômico. Publicado em 24.02.2016.

VASCONCELOS, Breno Ferreira Martins. MATTHIESEN, Maria Raphaela Dadona. Conceito de faturamento bruto excluídos os tributos para aplicação da pena de multa na lei anticorrupção. Revista dos Tribunais. V. 947/2014. São Paulo: Editora Revista dos Tribunais. Versão obtida digitalmente.

VENÂNCIO, Denilson Marcondes. Non bis in idem e as sanções administrativa, improbidade e penal. Fórum Administrativo - FA. V. 153. Belo Horizonte: Fórum, 2013. Versão obtida digitalmente. P. 26,40.

VENOSA, Sílvio de Salvo. Direito Civil. Parte Geral. 10ª Ed. São Paulo: Atlas, 2010;

VENTURI, Thaís Govea Pascoalato. A construção da responsabilidade civil preventiva no direito civil contemporâneo. Tese (Doutorado em Direito). 2012. Faculdade de Direito Universidade Federal do Paraná, Curitiba.

VERÍSSIMO, Carla. Compliance: incentivo à adoção de medidas anticorrupção. São Paulo: Saraiva, 2017.

VERZOLA, Maysa Abrahão Tavares. A sanção no direito administrativo brasileiro. 2008. Dissertação (Mestrado em Direito do Estado) - Faculdade de Direito, Universidade de São Paulo, São Paulo.

VIDAL, Marciano. Moral cristã em tempos de relativismos e fundamentalismos. $2^{\mathrm{a}} \mathrm{Ed}$. Aparecida: Editora Santuário, 2010.

VIEIRA, André Guilherme. "Imbroglio jurídico" ameaça lei, diz Adams. Jornal Valor Econômico. Publicado em 08 de maio de 2015. 
VIEIRA, Judivan J. Coleção corrupção no Mundo (Ferramentas de combate à corrupção, Perspectiva do direito internacional sobre corrupção, Perspectiva histórica da Corrupção, Perspectiva política da Corrupção, e Perspectiva jurídica da Corrupção). Brasília: Thesaurus, 2014.

VILANOVA, Lourival. Causalidade e relação no direito. $2^{\mathrm{a}}$ Ed. 1989.

VILLORIA, Manuel. JIMÉNEZ, Fernando. ¿Cuánta corrupción hay en españa? Los problemas metodológicos de la mención de corrupción (2004-2011). Revista de Estudios Políticos (nueva época). N. 156. Madrid: 2012. P. 13, 47.

VITTA, Heraldo Garcia. A sanção no direito administrativo. São Paulo: Malheiros, 2003.

VORONOFF, Alice. Direito administrativo sancionador. Belo Horizonte: Fórum, 2018.

WALDMAN, Ricardo Libel. Teoria do risco e filosofia do direito: uma análise jusfilosófica do parágrafo único do art. 927 do novo código civil. Doutrinas Essenciais de Responsabilidade Civil. Vol. 2. São Paulo: Revista dos Tribunais, 2011. Versão obtida digitalmente. P. 659, 679.

WELZEL, Hans. O novo sistema jurídico-penal: uma introdução à doutrina da ação finalista. Tradução, Prefácio e Notas de Luiz Régis Prado. São Paulo: RT, 2001.

WUNDERLICH, Alexandre. A responsabilidade penal por danos ambientais - do cenário atual à avaliação crítica ao modelo de imputação de entes coletivos e individuais trazidos pela Lei 9.608/1995 no Brasil. Revista Brasileira de Ciências Criminais. Vol. 114/2015. São Paulo: Revista dos Tribunais, 2015. P. 203, 221.

XAVIER, Christiano Pires Guerra. Programas de compliance anticorrupção no contexto da Lei $n^{o}$ 12.846/13: elementos e estudo de caso. 2015. Dissertação (Mestrado em Direito) Escola de Direito, Fundação Getúlio Vargas, São Paulo.

ZAFFARONI, Eugenio Raúl. La culpabilidad en el siglo XXI. Doutrinas Essenciais de Direito Penal. Vol. 3. São Paulo: Revista dos Tribunais, 2010. Versão obtida digitalmente. P. 337, 359 .

ZANCANER, Weida. Razoabilidade e moralidade na Constituição de 1988. Revista Trimestral de Direito Público. N. 62. São Paulo: Malheiros, 2015. P. 182, 188.

ZAVASCKI, Teori Albino. Processo coletivo. 6 ${ }^{\text {a }}$ Ed. São Paulo: RT, 2014. 
ZENKNER, Marcelo. Ministério Público e solução extrajudicial de conflitos. In RIBEIRO, Carlos Vinicius Alves (org.). Ministério Público. Reflexões sobre princípios e funções institucionais. São Paulo. Atlas, 2010. P. 317, 338.

ZOCKUN, Maurício. Comentários ao art. $1^{\circ}$. In DI PIETRO, Maria Sylvia Zanella; MARRARA, Thiago. Lei Anticorrupção comentada. Belo Horizonte: Fórum, 2017. P. 15, 21.

ZOCKUN, Maurício. Vinculação e discricionariedade no acordo de leniência. Colunistas. Portal "Direito do Estado". Publicado em 14 de abril de 2016;

ZYMLER, Benjamin; DIOS, Laureano Canabarro. Lei Anticorrupção. Uma visão do controle externo. Belo Horizonte: Fórum, 2016. 


\section{APÊNDICES}

APÊNDICE I - QUARTA RODADA DE AVALIAÇÃo - MESICIC

\begin{tabular}{|c|c|c|}
\hline \multirow{2}{*}{$\begin{array}{l}\text { APROVAÇÃO PELA } \\
\text { ASSEMBLEIA GERAL: } \\
\text { DISPOSIÇÕES } \\
\text { ANALISADAS } \\
\end{array}$} & \multicolumn{2}{|l|}{2012} \\
\hline & \multicolumn{2}{|c|}{ Art. III, $\S 9^{929}$ - Órgãos de controle superior } \\
\hline \multirow[t]{2}{*}{$\begin{array}{l}\text { PRINCIPAIS } \\
\text { RECOMENDAÇÕES }\end{array}$} & CGU & $\begin{array}{l}\text { 1. Instalar a Comissão de Coordenação de Controle Interno e } \\
\text { divulgar informações sobre os resultados de suas reuniões e } \\
\text { outras atividades por meio da Internet; } \\
\text { 2. Manter permanentemente atualizada a página eletrônica do } \\
\text { Conselho de Transparência e Combate à Corrupção, } \\
\text { garantindo a publicação das agendas e atas das reuniões } \\
\text { realizadas; } \\
\text { 3. Fortalecer a CGU, garantindo-lhe os recursos financeiros e } \\
\text { humanos necessários ao adequado cumprimento de suas } \\
\text { funções, inclusive buscando implementar um plano de } \\
\text { retenção de funcionários; } \\
\text { 4. Considerar a possibilidade de estabelecer uma norma } \\
\text { jurídica que disponha princípios e diretrizes gerais para as } \\
\text { atividades da CGU e das unidades de ouvidoria dos órgãos } \\
\text { do Poder Executivo Federal; } \\
\text { 5. Publicar e divulgar o manual de rotinas e procedimentos da } \\
\text { CGU; } \\
\text { 6. Estabelecer canais institucionais de cooperação e } \\
\text { coordenação das atividades da CGU e das da Comissão de } \\
\text { Ética Pública; } \\
\text { 7. Aprimorar as informações estatísticas relativas às } \\
\text { investigações disciplinares iniciadas pela Corregedoria- } \\
\text { Geral da União, que possibilitem estabelecer quantas } \\
\text { tiveram a execução das sançôes de demissão } \\
\text { comprometidas pela prescrição; } \\
\text { 8. Considerara a possibilidade de efetuar os ajustes necessários } \\
\text { à legislação a fim de ampliar os efeitos da declaração de } \\
\text { inidoneidade, de maneira que a pessoa punida continue } \\
\text { proibida, por um prazo razoável, de licitar, contratar e } \\
\text { manter contratos com a Administração Pública, nos três } \\
\text { Poderes e em todas as esferas de governo, e de tornar } \\
\text { obrigatória a alimentação do "Cadastro Nacional de } \\
\text { Empresas Inidôneas e Suspensas" e sua observância. }\end{array}$ \\
\hline & TCU & $\begin{array}{l}\text { 1. Considerar a possibilidade de criar o Conselho Nacional dos } \\
\text { Tribunais de Contas como órgão de controle administrativo, } \\
\text { financeiro e disciplinar desses tribunais, garantindo-lhe os } \\
\text { recursos humanos e financeiros necessários para o adequado } \\
\text { cumprimento de suas funções; } \\
\text { 2. Continuar a manter permanentemente atualizado o cadastro } \\
\text { de inabilitados pelo TCU para exercer cargo ou função de } \\
\text { confiança e considerar a possibilidade de efetuar os ajustes } \\
\text { normativos necessários para que esse cadastro seja de } \\
\text { consulta obrigatória pela Administração Pública; }\end{array}$ \\
\hline
\end{tabular}

${ }^{929}$ Cf. Art. III, $\S 9^{\circ}$, da Convenção de Caracas: “Art. III. Para os fins estabelecidos no artigo II desta Convenção, os Estados Partes convêm em considerar a aplicabilidade de medidas, em seus próprios sistemas institucionais destinadas a criar, manter e fortalecer: (...) 9. Órgãos de controle superior, a fim de desenvolver mecanismos modernos para prevenir, detectar, punir e erradicar as práticas corruptas." 


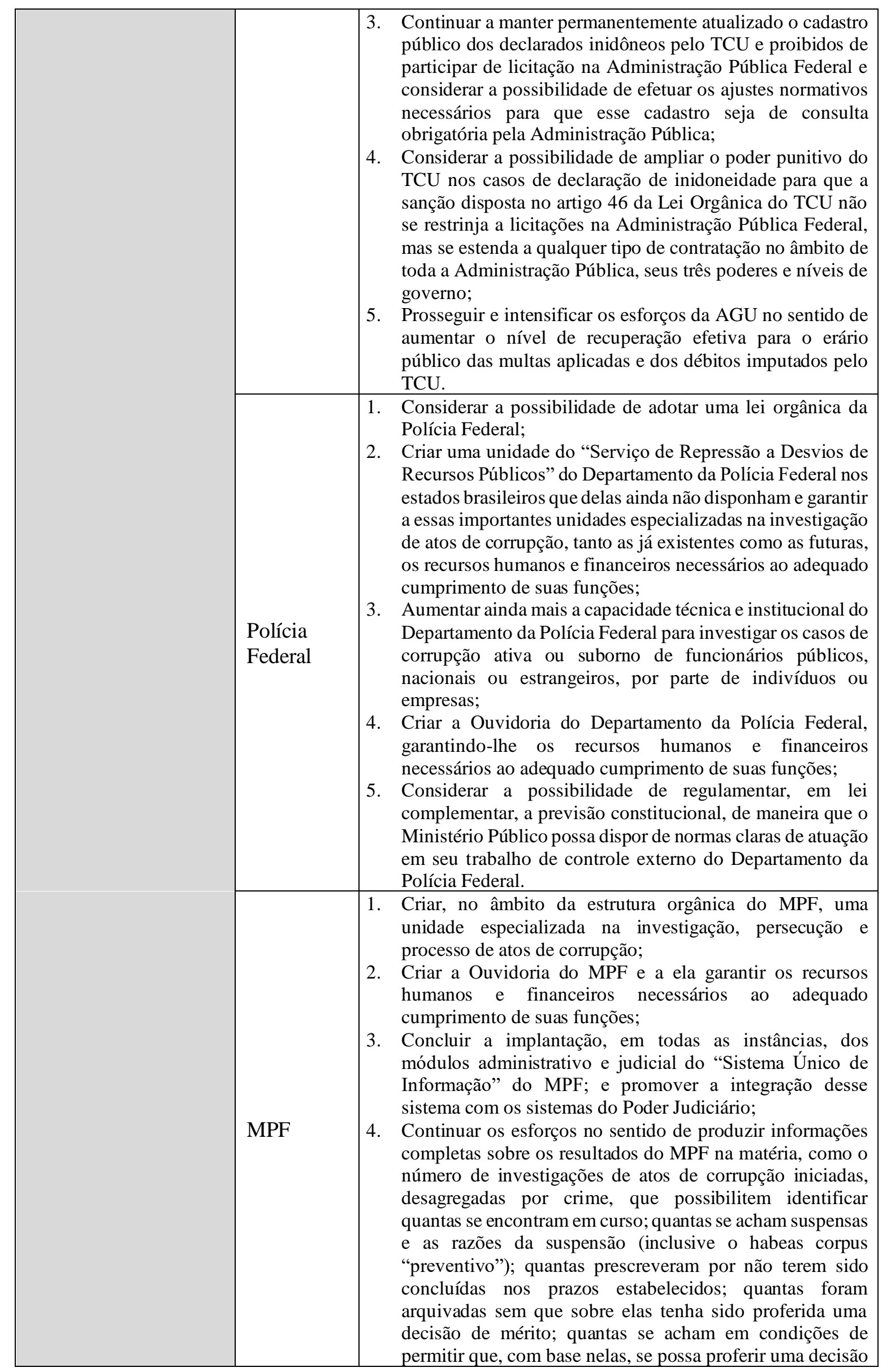




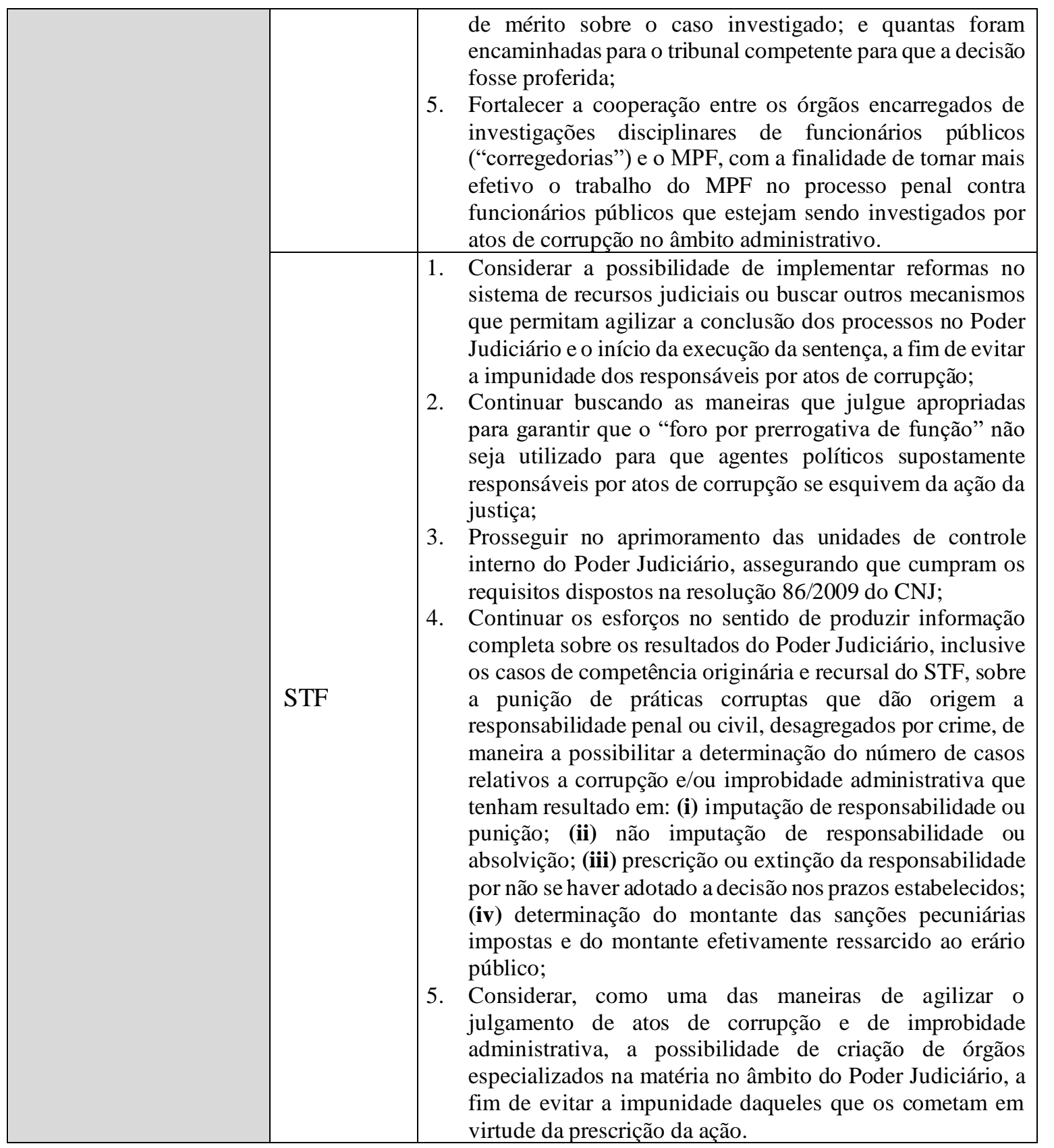

Fonte: Elaboração própria a partir dos dados disponíveis em: OEA. Relatório referente à implantação na República Federativa do Brasil da disposição da Convenção selecionada para ser analisada na quarta rodada e sobre o acompanhamento das recomendações formuladas ao país na primeira rodada. Washington: 2012. Disponível em http://www.oas.org/juridico/PDFs/mesicic4_bra_por.pdf. Acesso em 11.dez.2018. 